\title{
Secondary School Students' Feedback on Course Processing and Collaborative Learning with Web 2.0 Tools-Supported STEM Activities
}

\author{
Zafer BOLATLI a, Agah Tuğrul KORUCU*b
}

\begin{tabular}{l} 
Article Info \\
\hline DOI: \\
10.14686/buefad.358488 \\
\hline Article History: \\
Received: 28.11 .2017 \\
Accepted: 15.04 .2018 \\
Published: $\quad 30.06 .2018$ \\
\hline Keywords: \\
Web 2.0, \\
STEM, \\
Powtoon, \\
Technology integration, \\
Collaborative learning. \\
\hline Article Type: \\
Research article
\end{tabular}

\begin{abstract}
The aim of our work is to develop STEM activities supported by Web 2.0 tools and to examine the opinions of the students about collaborative learning method. The study group consists of six girls and six boys from seventh class secondary school students of Konya Selçuklu Sancak Secondary School in 2016-2017. Necessary corrections on STEM activity, developed by the researchers, were made by taking the opinions of 3 field experts and 1 language expert. This research is a descriptive study in qualitative structure. Semi-structured interview forms and video images were used to collect qualitative data. Video recording was conducted to gather opinions, behaviors and experience of using Web 2.0 tools on students' educational environment. According to the results of the training, the students expressed a positive opinion about STEM education method. It has been seen that students were having fun while using Web 2.0 tools and performing group work in the developed teaching environment. In addition, 10 students were positive about the collaborative teaching environment and 2 students were negative. Students stated that group work was useful when performing animation. The use of Web 2.0 tools increased the attention and motivation of the students.
\end{abstract}

\section{Ortaokul Öğrencilerinin Web 2.0 Araçlarıyla Desteklenmiş FeTeMM Etkinlikleriyle Dersin İşlenişine ve İşbirlikli Öğrenmeye Yönelik Görüşleri}

\section{MakaleBilgisi}

DOI:

$10.14686 /$ buefad. 358488

\begin{tabular}{lr}
\hline MakaleGeçmişi: \\
Geliş: & 28.11 .2017 \\
Kabul: & 15.04 .2018 \\
Yayın: & 30.06 .2018 \\
\hline
\end{tabular}

AnahtarKelimeler:

Web 2.0,

FeTeMM,

Powtoon,

Teknoloji entegrasyonu,

İşbirlikli öğrenme

MakaleTürü:

Araştırma Makalesi

\section{$\ddot{O} \mathbf{z}$}

Çalışmamızda Web 2.0 araçları ile desteklenmiş FeTeMM etkinliklerinin geliştirilmesi ve öğrencilerin işbirlikli öğrenme yöntemiyle dersin işlenmesine yönelik görüşlerinin incelenmesi amaçlanmaktadır. Çalışma grubu, Konya Selçuklu Sancak Ortaokulu 2016-2017 yılı 7.Sınıfa devam eden 6 kız ve 6 erkek ortaokul öğrencisinden oluşturulmuştur. Araştırmacılar tarafindan geliştirilen FeTeMM etkinliği üzerinde 3 alan ve 1 dil uzmanı görüşleri alınarak gerekli düzeltmeler yapılmıştır. Araştırma nitel yapıda betimsel bir çalışmadır. Nitel verilerin toplanması için yarı yapılandırılmış görüşme formlarından ve video görüntülerinden yararlanılmıştır. Öğrencilerin geliştirilen eğitim ortamı hakkında görüşlerinin, davranışlarının ve Web 2.0 aracını kullanım deneyimlerinin toplanması amacıyla video kaydı yapılmıştır. Araştırma sonuçlarına göre öğrenciler FeTeMM eğitim yöntemi konusunda olumlu görüş bildirmişlerdir. Öğrencilerin geliştirilen öğretim ortamında Web 2.0 araç kullanırken ve grup çalışması yaparken eğlendikleri görülmüştür. Ayrıca çalışmada işbirlikli öğretim ortamı hakkında 10 ögrenci olumlu, 2 öğrenci olumsuz görüş bildirmiştir. Öğrenciler, animasyon yaparken grup çalışmasının faydalı olduğunu belirtmiştir. Web 2.0 araç kullanımı öğrencilerin derse olan dikkatlerini ve isteklerini arttırdığı görülmüştür.

\footnotetext{
* Corresponding Author: akorucu@gmail.com

${ }^{a}$ Graduate Student, Necmettin Erbakan University, Konya/Turkey

b Assoc. Prof. Dr., Necmettin Erbakan University, Konya/Turkey, https://orcid.org/0000-0002-8334-1526
} 


\section{Introduction}

Nowadays, rapidly developing technology has quite too much influence on the education field, too. Different teaching environments have been developed as traditional teaching environment is inadequate today (Kayaduman, Sirakaya \& Seferoğlu, 2011). The use of technology by individuals and societies has made them stronger against events. At the same time, with the development of technological tools, people's lives have become easier. It helped individuals and societies to be stronger and to facilitate their lives in the face of events and events through the use of technology. Although technological developments bring along some opportunities, they burden individuals and societies with some responsibilities. Knowledge-based societies that are aware of their responsibilities integrate their lives and technology and are one step ahead of other societies (Gündüz \&Odabaş1, 2004). The most important skills that knowledge-based societies should possess are shown as science and mathematics (Yamak, Bulut \& Dündar, 2014). Attention given to science and mathematics-oriented education by societies that attach importance to technological developments and generation of information is increasing day by day. Due to the relation of science and mathematics to technology and engineering, this education spreads over the modern life. For this reason, it presents solutions to all the problems of the human being today and in the future (Yamak, Bulut \& Dündar, 2014).

The need for thinking, producing, questioning and creating individuals in science, technology, engineering and mathematics fields is increasing day by day(Gencer,2015). For this reason, application of new and different programs for teaching-learning processes in these fields is absolutely necessary. The most recent of these applications are the STEM education and applications.

STEM (Science, Technology, Engineering, Mathematics) term, which was introduced first in 2001 by Judith A. Ramaley, director of The National Science Foundation, has been rapidly spreading since then. The first letters of science, technology, engineering and mathematics, which are STEM courses were used to translate into our language. STEM term which has been developed as explained is named as a new teaching method. Although in the United States, the STEM educational environment has become widespread as an integration of mathematics and science courses at school level, it has been also described as teaching of engineering and technology with inclass and out-of-class activities (Ayar, Yalvac, Ugurdag \& Sahin, 2013;Şahin, Ayar \& Adıgüzel, 2014; Yıldırım \& Altun, 2015).

As a general definition, STEM can be named as teaching of the activities in courses by integrating science, technology, mathematics and engineering fields.

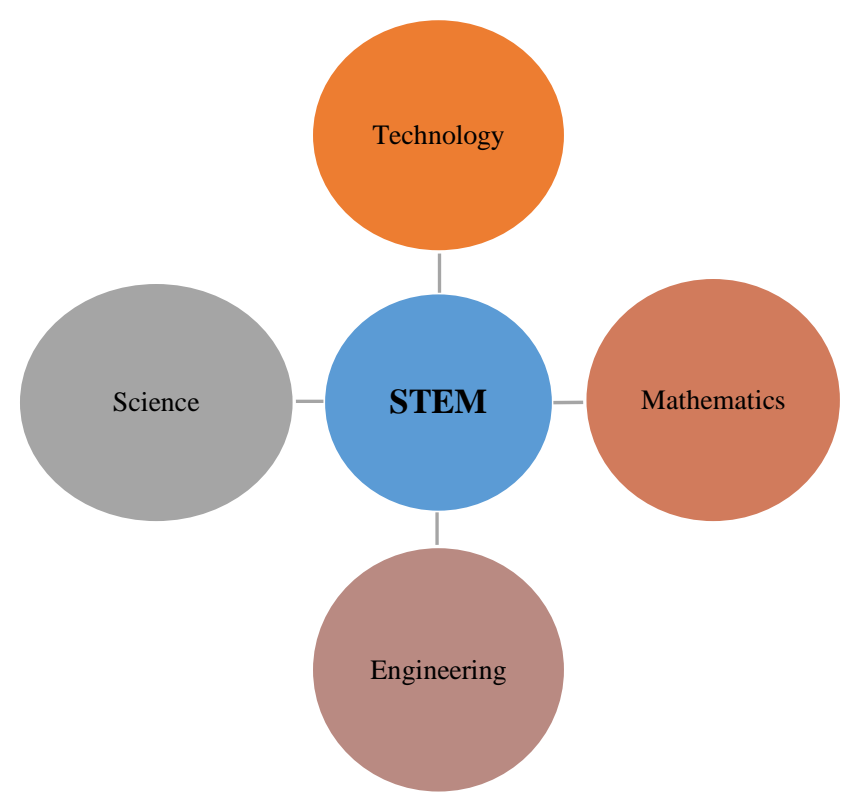

Figure 1. Diagram of STEM 
STEM offers two different program integration models in writing examinations. These can occur as content integration, multiple merging of STEM disciplines in activities and context integration, the use of different STEM contexts to make content more meaningful. STEM training focuses on specific learning and production activities that focus on skills such as research, design, problem solving, teamwork, and effective communication, rather than learning the aforementioned fields in isolation. The activities which can provide orientation of students towards science, technology, engineering and mathematics by using their 21 st century knowledge and skills are also involved in STEM education activities (Moore, Stohlmann, Wang, Tank \& Roehrig, 2014; Baran, CanbazoğluBilici \& Mesutoğlu, 2015).

It has been determined that the preference rate of STEM fields in our country has decreased significantly compared to the years. According to the OSYM (Student Selection and Placement Center) data between 2000 and 2014, the placement rates in STEM fields among the first 1000 students are presented in Figure-2. As seen in Figure-2, there is a significant decline in these fields over the years. However, after 2010, the prosperity of the STEM disciplines increased in our country with various activities and the OSYM placement rates started to rise again. While determining the placement percentages of STEM fields, engineering, computer, science and mathematics are included, whereas medical faculties are not included. The reason for this is that the National Science Foundation (NSF) defines its strategic plan as excluding the medical faculties from the disciplines of STEM and introduces the faculty of medicine as an establishment supporting all the basic science and engineering fields. NSF scientific organization indicates by this definition that faculty of medicine is not involved in the STEM fields. For this reason, medical faculties were not included in the data set presented in Chart 1. The student placement rate in STEM fields, which was $85.63 \%$ in 2000 declined to $27.88 \%$ in 2010.This suggests that the overall selection rate of STEM professions in Turkey is low. For this reason, it is urgent that the students should be encouraged for STEM fields. (Aydeniz et al., 2015).

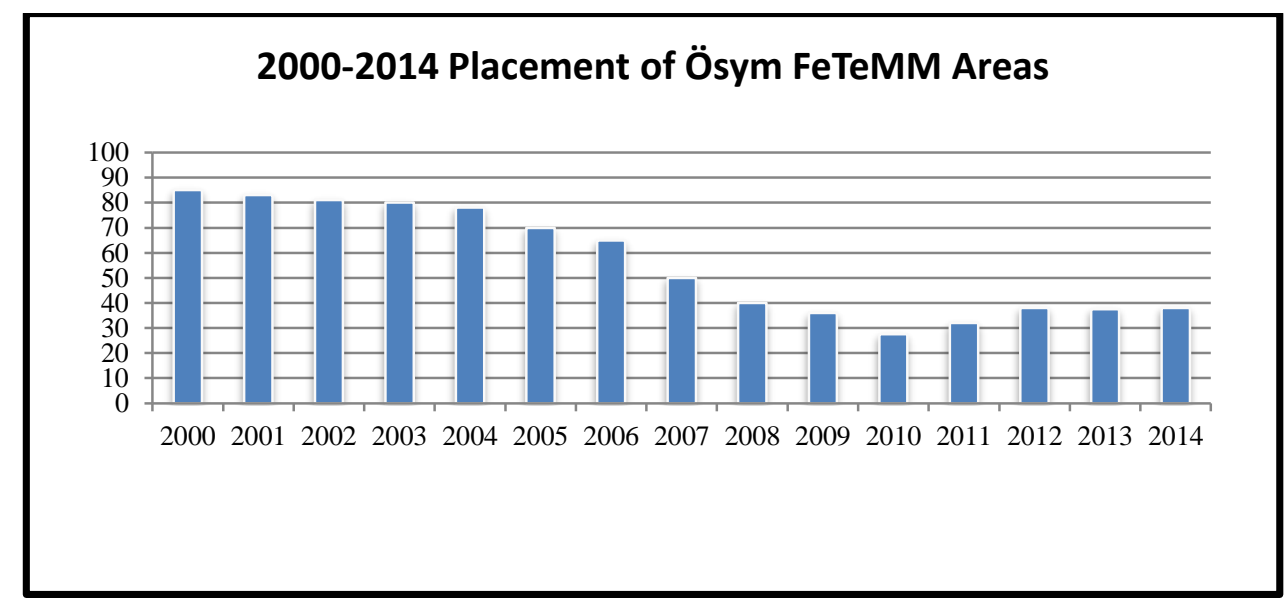

Figure 2. The placement rates of STEM fields by the first 1000 students who settled in numerical fields between 2000 and 2014 (Öğrenci Seçme ve Yerleştirme Merkezi [ÖSYM], 2015)

The results obtained from some researchers on STEM fields are as follows:

In STEM disciplines, it has strategic importance for our country to protect its international competitiveness. There are many criticisms that teachers in our country are not trained in the way that the age demands. Corlu and his colleagues have investigated ongoing educational reform initiatives performed in our country and the world in the field of curriculum integrated with teaching knowledge (Çorlu, Capraro \&Capraro, 2014). As a result of the research, when concentrated on the interaction between science and mathematics, which is the output of the conceptual model, they stated that it is not sufficient for raising the human power needed by our country by means of the teachers' knowledge only in the field which they were specialized (Çorlu, Capraro \&Capraro, 2014).

Another research performed in America concluded that the inadequacy of the education system and use of STEM teaching will make important contribution to the international competitiveness in the business world and the new economic thought of the United States. It was stated that the use of STEM fields in education of students will provide the necessary human power (Atkinson \& Mayo, 2010). 
In the STEM activity applied by the researcher, an example was established covered by scientific inquiry, science and engineering fields. The difference between engineering and science applications was determined also. In the research, students have the opportunity to test the prototype models, which are important steps in engineering, if they have a prior knowledge of the subject, and they are provided with the experience of developing new models. As a result of the research, it has been determined that this provided contribution in the formation of career consciousness in students in the future (Gencer, 2015).

Baran et al. (2015),web 2.0 was used in STEM activity which was developed in a research about the content and cover of STEM in field writing examinations. It was determined that the attitudes and information oriented towards STEM activities developed in the students. It was stated that the knowledge and skills of the students have developed in informatics technology subjects. In addition, it has been determined that STEM activity developed video design knowledge and design skills in students. The students expressed that when designing the STEM spot, they have experienced a better understanding of the content and cover of the STEM (Baran et al., 2015).

A similar another research it was determined that STEM education and application of engineering are effective in improving the success of students (Yıldirım \& Altun, 2015:37).

As a result of the examinations, it was observed that STEM activities provided significant contribution in teaching of the students. For this reason, in our research development of STEM activities supported by Web 2.0 tools and the opinions of students about performing the courses in a collaborative learning method were investigated.

\section{Aim of the Study}

The aim of this research is to develop the STEM activity for bio-variability issues in Science course and to examine the opinions of the students on the collaborative learning environment. We also aimed to plan STEM activity for providing the development needs of the students and the examination of the perceptions and experiences of the students using this teaching environment. For this purpose, the following questions were asked:

1. What are the opinions of the students about the use of STEM activities supported by Web 2.0 tools for teaching purpose?

2. How are the perceptions and experiences of the students and applicability process of STEM activities supported by Web 2.0 tools?

3. What are the opinions of the students about collection of STEM teaching environment with collaborative learning method?

4. What are the experiences and opinions of the students about the collaborative learning environment?

\section{Method}

This study is a descriptive qualitative research in order to investigate the development of STEM activities supported by Web 2.0 tools and the opinions of the students about performing the course with collaborative learning method. Descriptive researches describe a given state as fully and carefully as possible (Büyüköztürk, Çakmak, Akgün, Karadeniz \& Demirel, 2014: 22). It is not possible to talk about a common language in the qualitative researches which are performed in qualitative data analysis and rapidly improved in recent years. When the basic reference sources that focus on qualitative data analysis were investigated, it is possible to encounter quite different analysis methods and techniques (Dey, 1993; Özdemir, 2010). For this reason, in order to determine existing opinions, semi-structured interview method which is one of the qualitative research techniques was applied.

\section{Study Population}

The study group consisted of 6 girls and 6 boys who are $7^{\text {th }}$ grade students in Konya Selçuklu Sancak Secondary School in 2016-2017. The group of participants was created by random sampling among students. The students were divided into groups as 4 girls, 4 boys and 2 girls - 2 boys.

\section{Data Collection Tools}


In the study, the data was formed by asking the opinions of the participants with the semi-structured interview form created by the researchers and including necessary corrections due to the opinions of the experts. The responses and performances of the participants when they used the application were determined by video record.

Template of STEM Activity Application

\begin{tabular}{|c|c|}
\hline Activity No & 1 \\
\hline Subject & BIO-VARIABILITY \\
\hline Grade & 7th Grade \\
\hline Gain & $\begin{array}{l}\text { 1. Asks the importance of bio-variability for natural life. } \\
\text { 2. Discusses the factors threating bio-variability based on research data and } \\
\text { creates solution suggestions. } \\
\text { 3. Investigates plants and animals which are faced to become extinct in our } \\
\text { country and in the world. }\end{array}$ \\
\hline STEM Level & $\begin{array}{l}\text { Interaction of Science, Engineering, Mathematics, and Informatics Technology } \\
\text { Disciplines }\end{array}$ \\
\hline Tool & Animation Production (Powtoon) \\
\hline $\begin{array}{l}\text { Duration of the } \\
\text { Course }\end{array}$ & $\begin{array}{l}8 \text { Hours-320 minutes ( } 2 \text { weeks), } 2 \text { course hours are used for preparation and } \\
\text { presentation. }\end{array}$ \\
\hline Method & Demonstration-Trying, invention, expression, experiment \\
\hline \multicolumn{2}{|c|}{ APPLICATION STAGES } \\
\hline \multicolumn{2}{|c|}{ 1. Students are divided into groups of 4 students in each. } \\
\hline \multicolumn{2}{|c|}{$\begin{array}{l}\text { 2. The groups are requested to search for documents related to the subject via internet and asked to collect } \\
\text { them in a folder. }\end{array}$} \\
\hline \multicolumn{2}{|c|}{ 3. Pictures and texts related with the subject are given to the students in a folder prepared previously. } \\
\hline \multicolumn{2}{|c|}{ 4. Working paper describing bio-variability is given. } \\
\hline \multicolumn{2}{|c|}{$\begin{array}{l}\text { 5. Students are asked to perform experiments on biological variability that can be performed to prevent } \\
\text { nature. And they are asked to collect the notes and pictures of the steps of the experiment in a folder. } \\
6 \text {. The story for the animation is read to the students. It is told that they will perform the animation in this } \\
\text { direction. }\end{array}$} \\
\hline \multicolumn{2}{|c|}{ 7. Explain the tricks about animation. Multimedia design principles are mentioned. } \\
\hline \multicolumn{2}{|c|}{$\begin{array}{l}\text { 8. Students are asked to design what they can do on the stage of the animation on an empty sheet of paper. } \\
\text { Teacher support is provided to groups. }\end{array}$} \\
\hline \multicolumn{2}{|c|}{ 9. Powtoon Web 2.0 tool is introduced to students. A sample animation is demonstrated. } \\
\hline \multicolumn{2}{|c|}{ 10. A pre-prepared Powtoon working sheet is given to the students. The site address is told. } \\
\hline \multicolumn{2}{|c|}{ 11. Information is given that they can be a member of Powtoon or they can login via facebook-google. } \\
\hline \multicolumn{2}{|c|}{ 12. They are asked to perform animations about the subject. } \\
\hline \multicolumn{2}{|c|}{$\begin{array}{l}\text { 13. Sufficient time is leaved for animation. Required help for the experienced problems is provided by the } \\
\text { researcher and course teacher. }\end{array}$} \\
\hline \multicolumn{2}{|l|}{ In stages; } \\
\hline The student prep & imation about bio-variability and the murder of our nature. \\
\hline
\end{tabular}


a. The student makes an entry scene to take into consideration the theme.

b. A graph presenting the living species at risk of extinction is animated

c. A template is created that presents why these livings are at risk of extinction.

d. The pages that show what kind of environmental pollution is occurring or the livings at risk of extinction are formed. They can demonstrate their researches and experimentation stages (at least three pages are formed).

e. Attention is drawn to what everyone can do to prevent nature and bio-variability from disappearing.

f. Animation is ended with a slogan.

\section{STEM Spot Example Developed by the Participants}

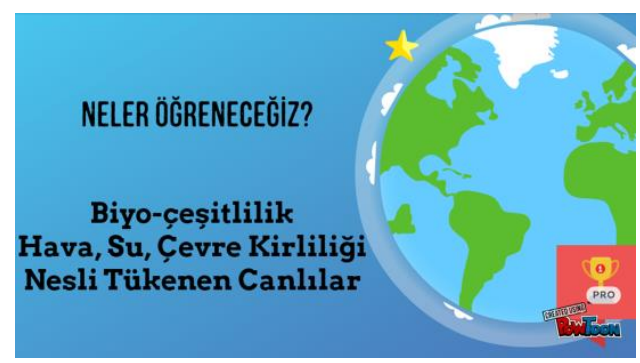

Figure 3. Login Screen

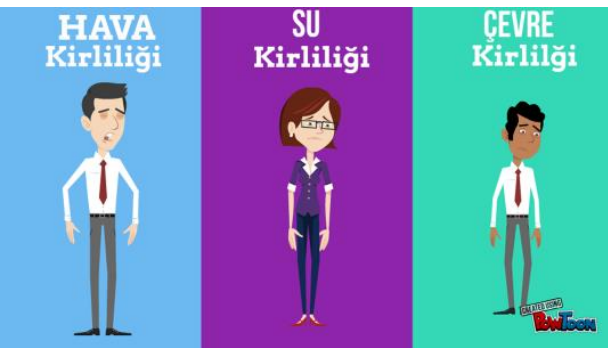

Figure 4. (b) Subject Lecturing

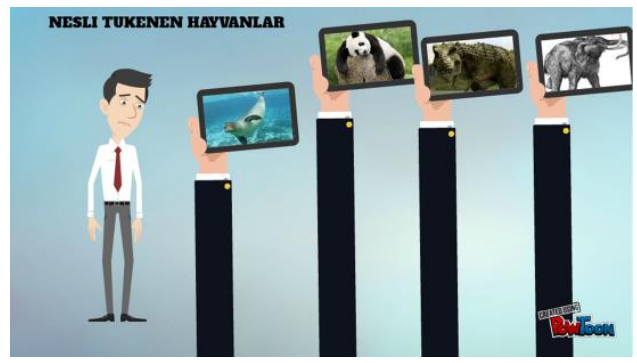

Figure 4. (d) Subject Lecturing

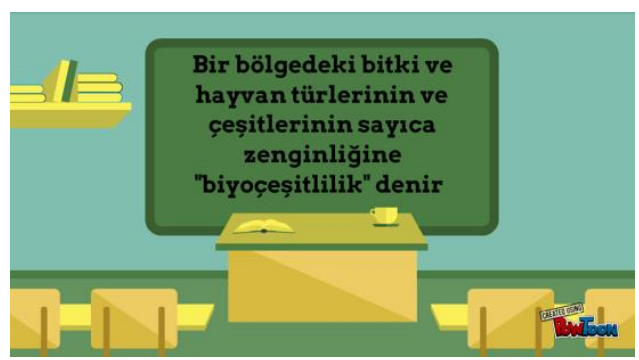

Figure 4. (a) Subject Lecturing

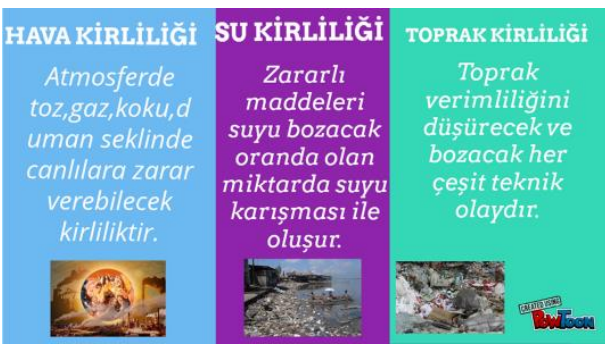

Figure 4. (c) Subject Lecturing

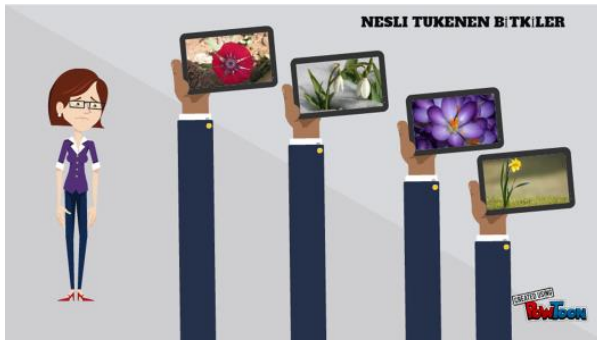

Figure 4 (e) Subject Lecturing 


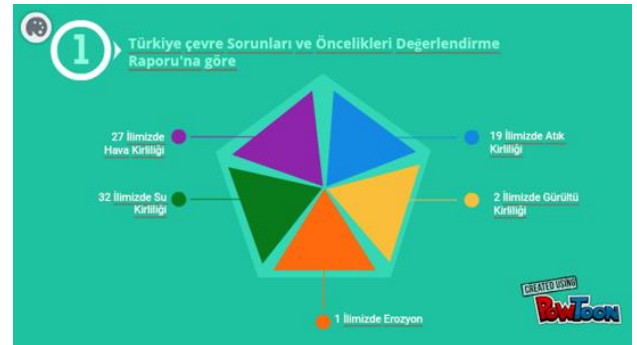

Figure 5. Graphical Subject Lecturing

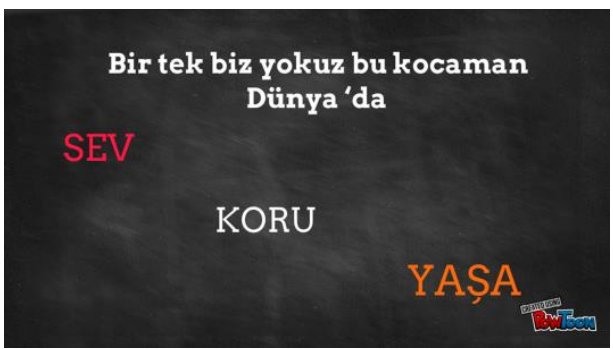

Figure 6. Slogan end Finish

\section{Findings}

The students performed the tasks given in the improved STEM teaching environment. Students completed the 2 -week Science course bio-variability content $(4+4$ Course Hours $)$ within the given time period. STEM activities have been held in the library and a free classroom in order to prevent the students meet the probable problems during the teaching environment. Video recording was conducted to examine how the teaching process has taken place. Problems experienced by the students and their mimicry and movements during the application are recorded in video recording. After the completion of the STEM activities, the semi-structured collaborative learning and course feedback form was filled out by students. The students were asked about their opinions related with the process during the video recording. General ideas about the teaching environment developed during the video recording were asked and recorded. As a result of the semi-structured interview form and video recordings:

When the findings are given, the users are coded as follows.

G1-GS: Group1 Girl Students, G1-BS: Group 1 Boy Students, G1-LS: Group 1 Leader Student, G2-BS: Group 2 Boy Students, G2-LS: Group 2 Leader Student, G3-GS: Group3 Girl Students, G3-LS: Group 3 Leader Student,

\section{Opinions of the students about using STEM activities supported by Web 2.0 tools for teaching purposes and results:}

All of the students reported positive opinions about the teaching environment developed by the researchers. The views of the group leader; G1-LS (G1-GS1) coded student told about what she have learned during the preparation phase of the animation without being aware of what she was doing. G2-LS (G2-BS1) stated that information is persistent because of the high number of visual themes and they have completed the process without getting bored. The group leader, G3-LS (G3-GS1), stated that they have enjoyed the developed teaching environment and that they have learned a lot of information in a shorter time than the normal course. She also stated that "this method should be absolutely in education-teaching"

From the other members of the group, G1-GS2 and G1-BS2, stated that they had learned the subject without being bored and that they had completed the exercises in a short time in terms of time use. However, two computers should be given to the group and this can provide the animation be better. G1-BS1 stated that the application of the developed activities was a bit difficult at first, but the teaching environment was amusing. In the video recordings examined, G1-BS1 seemed to have joined the courses late and missed certain sections. The motivation of the student in teaching environment was affected negatively by this situation.

Students with G2-BS2 and G2-BS3 code stated that the science course should always be performed in this way. They have emphasized that teaching will be permanent and courses will be easy to learn. The student with G2BS4 coded "I had fun during the teaching process but occasionally I needed the teacher's explanation". He stated that it will be useful for learning if the teacher could explain the subject in summary.

G3-GS2, G3-GS3 and G3-GS4 coded students stated that learning was easy with the developed teaching environment and that they have learned a lot of different information during the research. They have also emphasized that this method is enjoyable and memorable.

2. The results about the processes, perceptions and experiences of the students performing STEM activities supported by Web 2.0 tools: 
The ability and experiences of STEM activities by the students seem to be positive. The disconnection or slowing of the internet network sometimes caused some problems in the process. It was seen that our students who performed the animation for the first time remembered some functions they had forgotten in their computer skills. It has been determined that they had some difficulties because they had used the Web 2.0 for the first time. G1-LS (G1-GS1) coded student stated that she remembered some computer skills she had forgotten with this teaching environment. It was the first time they used a Web 2.0 tool to animate, and at the beginning they met difficulty, but then they easily used it. From the group members G1-BS1 seemed to be negatively affected by the process either because of the wish to become a leader or her being late. G2-LS has expressed that animation can be performed easily in this way and that they had fun while learning the subject. In the video recording examinations, it was observed that the group leaded their friends who had the high skills to use technology. By this way and with the information they learned in the coordination of the leader student, it was observed that the animations were completed quickly. The Internet problems of Group 2 members have affected the process negatively. G3-LS, the group leader stated that they enjoyed the process but expressed difficulty while using the computer. He also said that "I feeled self-confident with the difficulties that have been experienced and have been able to fight against the difficulties." He stated that the process was amusing and should be used in the educational environment.

G1-GS2 stated that it was difficult to set the time and use the web 2.0 tool, but they have learned in a short time. She stated that they had overcome some difficulties with the help of the teacher and they had fun in the process. According to video recordings they had taken place in the research and animation template creation section of the group. It was determined that they had fun while performing the animation and this had a positive effect on the process. G1-BS1 reported negative opinion about the process since he was late to the activity application days. He said that he could continue the process more easily by himself. He stated that the process was amusing, but it has taken some time. G1-BS2 stated that the teachers and their friends had completed the subjects they did not know and this raised his interest in the lesson. He stated that the teaching media was successful and the courses should be performed in this way.

G2-BS1, G2-BS2, G2-BS3 and G2-BS4 were determined to have fun in the developed teaching environment. However, due to short-term internet connection problems, it has been determined that they were bored for a while during the use of Web 2.0 tools. Despite the negativity they experienced, they expressed that the process was positive. They pointed out that the motivation of the students will increase with the effect of this process. They stated that the educational process was very good except for the speed of the internet connection. They expressed the views that the activities could be done easily.

G3-GS1 stated that she had fun during the developed teaching environment, but have expressed a little difficulty in becoming a group leader. She stated that some of the members occasionally leaved the group and this disturbed the harmony of the group. She also said, "As we used the Web 2.0 tool we leaved the planned animation template and learned different things." She has expressed her opinion that this situation motivated them positively and they did not understand how quickly the course passed. G3-GS2, G3-GS3 and G3-GS4 stated that the process was useful for them and the course had passed easily without being bored. They told that the leader of the group went beyond the content of the planned animation and produced a more successful product. G3-GS3 was also found to have difficulty during the research and Web 2.0 tool use, and it was determined that she left the group positively rom the process with the support of the group members and the teachers.

3. The opinions of the students about the collection of the STEM teaching environment with the collaborative learning method and the findings:

As a result of the students' group work in the STEM teaching environment, 10 students stated positive and 2 students negative opinion. It was determined that the students who expressed negative opinions were students who were late to the classes and the leadership characteristics were significant for them. All group leaders expressed positive opinions for the method used. G1-LS stated that by means of the applied method it was necessary to use previous computer skills and knowledge about a lot of lessons. Throughout the process, they expressed that they had fun with their friends and did not understand how the time passed. It was seen that the mixed group was the first that completed the process.It is also observed that the group members distributed tasks among each other and the leader actively inserted group friends in the completion of the process. G1-BS2 and G1-GS2 indicated their opinion that computer and science skills were developed in the activities applied within group work. G1-BS2 says, "My friends helped me in matters that I did not know, and I tried to help while they did not know." G1-BS1 
indicated negative opinion about the improved teaching environment. "I could have done this work better by myself, not as a group."

G2-LS said, "We are pleased that we have fun while working with our group friends." And he also expressed that they understood the subject well by this way and their attendance to the course was at the highest level. It has been found that this group of boys had much more fun with their mimics. As the leader of the group did not plan the distribution of tasks well, various problems occurred during the application. On the other hand, G2-BS2 stated that he learned the truth of many misinformed knowledge by means of group work with STEM activities and remembered the forgotten computer skills with G2-BS3. G2-BS4 indicated that he had enjoyed during the developed teaching environment, but for clarification of some subjects, "Process provided a positive contribution, but I need the teacher's knowledge in order to fully learn the subject".

G3-LS stated that collaborative learning was already an entertaining process and a good teaching environment as it was presently known. In the girl group it was seen that the group was divided into two. While the G3-GS1 and G3-GS4 undertook the task in majority, the G3-GS2 and G3-GS3 were observed as passive in the group. But it was seen that they have merged over time and enjoyed themselves. G3-GS2 stated that the knowledge was easy to understand in the developed teaching system and they experienced active class attendance by means of the activities. G3-GS4 stated that "Students will enjoy this system very much". But G3-GS2 expressed negative opinion about group work. However she indicated that she enjoyed STEM activity.

\section{The experiences and opinions of the students about the collaborative learning environment and the findings:}

G1-LS answered the question 'what was the thing you enjoyed within collaborative learning?' as the group members were 2 girls and 2 boys, and this provided looking through different ways while they were animating and they had fun during the process. They pointed out that conflicting ideas existed during collaborative learning; however they met at the same decision within the activity. He also said, "I learned about the different features of my friends through group work." He said that he did not experience any problem when communicating with his group of friends. G1-GS2 indicated her opinion as 'I enjoyed animating with group members'. It was determined that her interaction was good with the group friends and helped each other in group. G1-BS1 stated that everybody combined knowledge and they were able to solve problems in group work. In another expression, he expressed his opinion that the leader of the group should be chosen carefully. Due to being late to classes, it seems that they have been excluded from the group in certain periods. But over time, he has made himself to be assumed as a member of the group and has been actively involved in the activities. He expressed also that the task makes one busy and time consuming. He indicated negative opinion as the collaborative learning environment was not suitable for him. G1-BS2 stated that "The leader of the group did not take charge of any work by himself but distributed the task among us and I was pleased about this." He also expressed his opinion that he realized his skills after group work and that he would do better with homeworks and classroom activities from now on. "My friend, who was late to the group, joined any discussion without being aware of the matter, and declaring ideas on the contrary to the leader negatively affected the communication between us." He emphasized the communication between the members of the group by this way.

G2-LS, G2-BS and G2-BS2 expressed that they had a lot of fun while working with their group friends. In addition, G2-LS said that at the beginning, he thought that his group friends were not good, but by the process progresses he realized that he was wrong and then they became good friends. Similarly, G2-BS2 and G2-BS3 stated that they were benefiting from their friends' knowledge while group work and an intimate friendship developed among them. G2-BS1, indicated his opinion as 'For group work to be productive, communication between group members needs to be good, and the technological tools to be used must be fast."G2-BS3 has pointed out the point that should be taken into consideration as "Ideas must be shared among friends". G2-BS4 have stated that they were receiving support from the teacher for the difficulties experienced in group work and they required help in matters they do not know. He also commented as "I did not think my groupmate G2-BS2 used computer so successfully".

G3-LS stated that some of his friends did not enoughly support and take responsibility for his group work. In video recordings, it was seen that two group members sometimes moved out of the group as G3-LS stated. This situation had negatively affected group dynamics. As for the issues that need to be taken care of in the group work, it is expressed as "I think it is necessary for my group friends to be sincere and open to every opinion and ask for 
help in difficult times."G3-GS2 stated that the opinions of the group friends should be taken during the activities. He also indicated that communication between group friends has improved in the positive direction. G3-GS3 and G3-GS4 stated that the task distribution must be done when performing group work. In addition, G3-GS4 stated that their group mates were better than they thought.

In the video recording examinations, it was found that the mixed group cooperated better than the other members. Experiencing internet connecting problems caused for the male student group to have negative opinions. In Group 1, there were two students who wanted to lead, caused disruptions during practice. It has been seen that the students had fun while using the Web 2.0 tool.

\section{Discussion and Conclusion}

There are many studies about STEM in the literature. Yıldirım and Altun (2015), in a study investigating the effects of the STEM education and engineering applications on science laboratory practice determined significant increase in the degree of learning (Yıldırım \& Altun, 2015). This situation overlaps with the fact that the students were positive about the developed educational environment. The use of Web 2.0 tools for teaching seems to make the teaching process fun. The students seemed to have used many skills without realizing during STEM activities. In a similar research, Germann, Aram and Burke (1996) stated that experiments in science labs on 7th grade students would improve students' cognitive processes and thought skills (Germann, Aram \& Burke, 1996).In another research conducted by Sullivan (2008), the STEM activities of secondary school students reported that the cognitive process skills of students improved (Sullivan, 2008). Stohlmann, Moore and Roehrig (2012), pointed out that STEM education is important in making what the students learned sense and should be developed at secondary school level in a field study performed about the factors that should be taken into consideration in integration of the STEM education method with the existing system (Stohlmann, Moore \& Roehrig, 2012). In our research, it was determined that students' views on the use of STEM activities supported by Web 2.0 tools for teaching purposes were positive. Also the comments of the students were in the direction of integrating the developed environment into the existing system.

According to another result reached in the research, the process, perceptions and experiences of students about STEM activities supported by Web 2.0 tools were generally positive. It was seen that some students had difficulty when performing Web 2.0 tool activity, but they solved the use of the tool in a short time.

Karahan, Cambazoğlu-Bilici and Ünal (2015) stated that they enjoyed and enjoyed the STEM activities in their 8th grade classes (Karahan, Cambazoğlu-Bilici \& Ünal 2015).In our research, the use of Web 2.0 tools has been found to make the STEM education amusing.

The design-based science education that Çavaş, Bulut, Holbrook and Rannikmae (2013) made was found to increase the interest and desire of the students (Çavaş, Bulut, Holbrook \& Rannikmae, 2013). Parallel to this situation; it has been seen that the students liked the improved teaching environment with Web 2.0 tools and the learning desires were increased. It was seen that the students were disturbed from time to time by the speed of the internet. In the case of internet and computer use in STEM activities, once again the importance of network is seen.

Sahin, Ayar and Adigüzel (2014) stated that during the STEM activities students' group work cooperatively developed such as the 21st century skills (Şahin, Ayar \& Adıgüzel, 2014)The research supports this situation. The students expressed a positive opinion on the collection of the STEM teaching environment with the Collaborative Learning method. The fact that the students supported each other during the STEM training affected the process positively. In the events organized, the members of the group made division of the labor and helped each other to increase the quality of the product. In addition, the students with strong leader characteristics being members of the group were effective in the success of activities. The group members' having different views helped them to develop different interpretations of the STEM activities. It has been determined that the students have solved their problems when they encountered a problem. It was thought that the students have developed problem solving skills by means of the developed teaching environment.

Students' experiences and opinions about the collaborative learning environment seemed to be generally positive. It was seen that the mixed groups acted from a different point of view to the events and activities than the other groups. The group formed from male students group was found to be more compatible with their friends and be in closer communication than other groups throughout the process. In the group formed from female 
students, it was seen that they were sometimes disrupted in the process because there was not a group leader as it was desired. During the group study, it was observed that the students made the desired things during the course without getting bored. It has been found that self-esteem develops in students who think that they are inward and failing with group work. The fact that the students were active in the educational environment developed in the group work influenced the success of the process positively. For this reason, we think that the STEM activities supported by Web 2.0 tools should be prepared in a way to provide active participation of the students.

\section{Acknowledgments}

Executed summary (oral presentation) of this research is presented in ICITS-2017 (International Computer \& Instructional Technologies Symposium). 


\section{Ortaokul Öğrencilerinin Web 2.0 Araçlarıyla Desteklenmiş FeteMM Etkinlikleriyle Dersin İşlenişine ve İşbirlikli Öğrenmeye Yönelik Görüşleri}

\section{Giriș}

Günümüzde hızla gelişmekte olan teknoloji eğitim alanını da oldukça fazla etkilemektedir. Geleneksel öğretim ortamının yetersiz kaldığı günümüzde farklı öğretim ortamları geliştirilmektedir (Kayaduman, Sırakaya \& Seferoğlu, 2011). Bireylerin ve toplumların, teknolojiyi kullanması olaylar ve olgular karşısında daha güçlü olmasını sağlamıştır. Aynı zamanda teknolojik araçların gelişmesiyle insanların yaşamını kolaylaşmıştır.. Teknolojik gelişmelerin beraberinde getirdiği imkânların yanında, teknoloji bireylere ve toplumlara bazı sorumluluklarda yüklemiştir. $\mathrm{Bu}$ sorumluluklarının farkında olan bilgi toplumları,yaşamları ile teknolojiyi bütünleştirmiş ve bu durum diğer toplumlardan hep bir adım daha önde olmalarına destek olmuştur(Gündüz \& Odabaşı, 2004).Bilgi toplumlarının sahip olması gereken en önemli beceriler fen ve matematik alanı olarak gösterilmektedir(Yamak, Bulut \& Dündar, 2014). Teknolojik gelişmelere ve bilgi üretmeye önem veren toplumların fen ve matematik ağırlıklı eğitime verdikleri önem gün geçtikçe artmaktadır. Fen ve matematiğin teknoloji ve mühendislikle olan ilişsisinden dolayı bu eğitim modern hayata yayılmaktadır. Bu sayede insanoğlunun günümüzdeki ve gelecekteki problemlerine çözüm sunmaktadır (Yamak, Bulut \& Dündar, 2014).

Günümüzde fen, teknoloji, mühendislik ve matematik alanlarında düşünen, üreten, sorgulayan ve yaratıcı bireylere olan ihtiyaç gün geçtikçe artmaktadır (Gencer,2015). Bu nedenle, bu alanlarda öğretmeöğrenme süreçleri için yeni ve farklı programların uygulanması zorunlu olmuştur. Bu uygulamaların en yeni olanı FeTeMM (STEM) eğitim ve uygulamalarıdır.

2001 yılında The National Science Foundation yöneticisi Judith A. Ramaley tarafından ileri sürülen STEM (Science, Technology, Engineering, Mathematics) terimi, bu tarihten itibaren hizla yayılmıştır.Dilimize çevrilirken STEM dersleri olan fen bilimleri, teknoloji, mühendislik ve matematik sözcüklerinin ilk harfleri kullanılmıştır. Bu şekilde ortaya çıkan FeTeMM kavramı, yeni öğretim yöntemlerinden biri olarak adlandırılmıştır. Amerika Birleşik Devletleri'nde FeTeMM eğitim ortamı okul düzeyinde matematik ve fen bilimleri derslerinin bütünleştirilmesi olarak yaygınlaşmış olsa da mühendislik ve teknolojinin ders içi ve ders dışı etkinlikler ile öğretilmesi olarak tanımlanmıştır (Ayar, Yalvac, Ugurdag\& Sahin, 2013;Şahin, Ayar \& Adıgüzel, 2014; Yıldırım \& Altun, 2015).

FeTeMM en genel anlamıyla; fen, teknoloji, matematik ve mühendislik alanlarının bütünleştirilerek derslerdeki etkinliklerin öğretilmesi olarak adlandırılabilir.

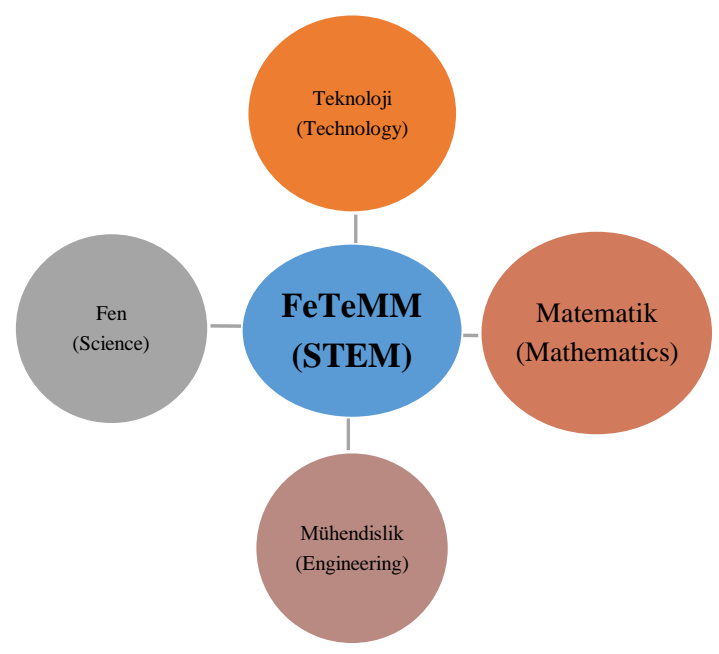

Şekil 1. FeTeMM Şeması

Alanyazın incelemelerinde FeTeMM iki farklı program entegrasyon modeli sunmaktadır. Bunlar içerik entegrasyonu, etkinliklerde FeTeMM disiplinlerinin birden çok birleştirilmesi, ve bağlam entegrasyonu, 
içeriği daha anlamlı kılmak için farklı FeTeMM bağlamlarının kullanımı olarak görülmektedir. FeTeMM eğitimi adı geçen alanların birbirinden izole bir şekilde öğrenilmesi yerine, araştırma, tasarım, problem çözme, takım çalışması ve etkili iletişim kurma gibi becerilere odaklanan özgün öğrenme ve üretme etkinliklerine odaklanmaktadır. Öğrencilerin 21. yüzyıl bilgi ve becerilerini kullanarak fen, teknoloji, mühendislik ve matematik alanlarına yönelimlerini sağlayacak faaliyetler de FeTeMM eğitim etkinlikleri kapsamındadır (Moore, Stohlmann, Wang, Tank \& Roehrig, 2014; Baran, Canbazoğlu-Bilici \& Mesutoğlu, 2015).

Ülkemizde FeTeMM bölümlerine tercih etme oranı ise yıllara göre belirgin bir düşüş yaşandığı tespit edilmiştir.2000-2014 yılları arasında ÖSYM (Öğrenci Seçme ve Yerleştirme Merkezi) verilerine göre FeTeMM alanlarına, sınavda ilk 1000 içine giren öğrenciler arasındaki yerleştirme oranları Şekil-2'de görülmektedir. Şekil-2'de görüldüğü üzere bu alanlarda yıllara göre belirgin bir düşüş bulunmaktadır. Fakat ülkemizde 2010 yılından sonra FeTeMM disiplinlerinin önemi çeşitli etkinliklerle artmış ve ÖSYM yerleştirme oranları tekrardan yükselmeye başlamıştır. FeTeMM alanlarının yerleştirme yüzdeleri belirlenirken mühendislikler, bilgisayar, fen bilimleri ve matematik bölümleri dahil edilirken, tıp fakülteleri dahil edilmemiştir. Bunun sebebi NSF (National Science Foundation), stratejik planında tıp fakültelerini FeTeMM disiplinlerinin dışında tutmuştur.NSF, tüm temel bilim ile mühendislik alanlarını destekleyen bir kuruluş olarak tanımlamaktadır. Bu tanımla NSF, tıp fakültelerinin FeTeMM alanı içerisinde yer almadığına işaret etmektedir.Bu sebeple Şekil-2'de oluşturan verilere tıp fakülteleri dâhil edilmemiştir. FeTeMM alanlarına 2000 yılında \%85,63 olan öğrenci yerleştirme oranı 2010 yılında \%27,88'lere kadar gerilemiştir. $\mathrm{Bu}$ durum Türkiye genelinde FeTeMM mesleklerinin seçilme oranın düşük olduğunu göstermektedir. $\mathrm{Bu}$ durum FeTeMM alanına öğrencilerin teşvik edilmesi gerektiğini göstermektedir. (Aydeniz ve diğerleri, 2015).

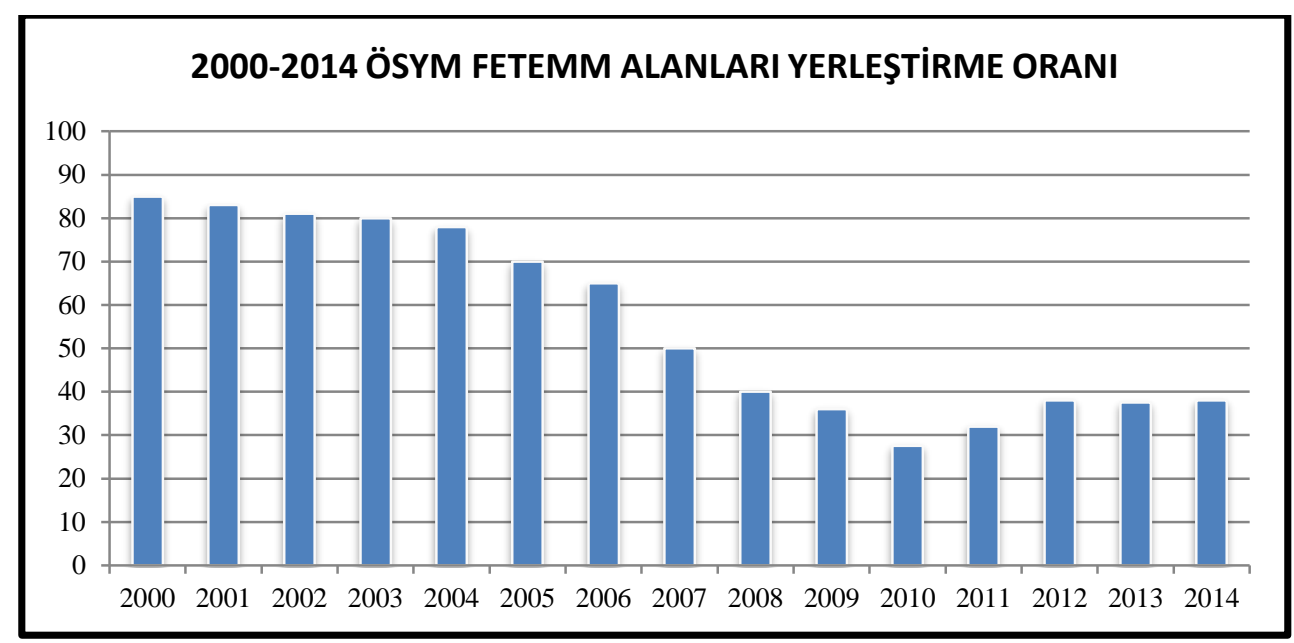

Şekil 2. 2000-2014 yılları arasında sayısal alanlarda yerleşen ilk 1000 öğrencinin FeTeMM alanları yerleştirme oranları (Öğrenci Seçme ve Yerleştirme Merkezi [ÖSYM], 2015)

FeTeMM alanında yapılan bazı çalışmalarda şu şekilde sonuçlara varılmıştır;

FeTeMM disiplinlerinde ülkemizin, uluslararası rekabet gücünü koruyabilmesi stratejik öneme sahiptir. Ülkemiz öğretmenlerinin çağın gerektirdiği şekilde eğitilmedikleri konusunda birçok eleştiri bulunmaktadır. Çorlu ve arkadaşları yaptıkları araştırmada öğretmenlik bilgisi ile bütünleşik müfredat alanlarında ülkemizde ve dünyada yapılmış araştırmalar ile süregelen eğitim reform girişimlerini araştırmıştır(Çorlu, Capraro \&Capraro, 2014). Araştırma sonucunda ise kavramlaştırılan modelin bir çıktısı olan fen ve matematik arasındaki etkileşime yoğunlaştırdığında, öğretmenlerin sadece uzman oldukları alanda öğretmenlik bilgisine sahip olmalarının ülkemizin ihtiyacı olan insan gücünü yetiştirmede yeterli olmayacağı sonucuna varmıştır(Çorlu, Capraro \&Capraro, 2014). 
Amerika da yapılan bir diğer araştırma; eğitim sistemindeki yetersizliklerin FeTeMM öğretiminin kullanılmasının sanayi ve iş dünyasında uluslararası rekabette ve ABD'nin yeni ekonomik düşüncesinde önemli katkılarda bulunacağı kanısına varmıştır. FeTeMM alanların öğrenci eğitimlerinde kullanılması gerekli yüksek iş gücü getireceği belirtilmiştir (Atkinson \& Mayo, 2010).

Diğer bir araştırmada araştırmacı tarafından uygulanan FeTeMM etkinliğinde, bilimsel sorgulama, bilim ve mühendislik alanlarının kapsadığı bir örnek oluşturulmuştur. Ayrıca mühendislik ve bilim uygulamaları arasındaki fark tespit edilmiştir. Araştırmada öğrencilerin konu ile ilgili ön bilgileri varsa mühendislikte önemli bir adım olan prototip modelleri test etmesine imkan tanınmış ve yeni modelleri geliştirme deneyimleri yapmaları sağlanmıştır. Araştırma sonucunda bu durumların öğrencilerin gelecekteki süreçte kariyer bilincinin oluşmasına katkı sağladığı tespit edilmiştir (Gencer, 2015).

Alanyazın incelemelerinde Baran vd. (2015) tarafından yapılan FeTeMM içeriği ve kapsamı ile ilgili yapılan bir araştırmada geliştirilen FeTeMM etkinliğinde Web 2.0 aracı kullanılmıştır. Yapılan incelemelerde öğrencilerde FeTeMM etkinliklerine yönelik tutum ve bilgilerin geliştiği tespit edilmiştir. Öğrencilerin bilişim teknolojileri konularında bilgi ve becerilerinin geliştirildiği belirtilmiştir. Ayrıca geliştirilen FeTeMM etkinliğinin öğrencilerde video tasarım bilgi ve tasarım becerilerine olumlu katk1 sağladığı tespit edilmiştir. Öğrenciler FeTeMM spotunu tasarlarken FeTeMM içeriği ve kapsamını daha iyi anladıklarını ifade etmişlerdir(Baran ve diğerleri, 2015).Benzer biçimde gerçekleştirilen bir diğer araştırmada ise, FeTeMM eğitimi ve mühendislik uygulamalarının öğrencilerin başarılarını geliştirmede etkili olduğu tespit edilmiştir (Yıldırım \& Altun, 2015:37).

Yapılan incelemeler sonucunda FeTeMM etkinliklerinin öğrencilerin öğretimine önemli derece katk1 sağladığı görülmektedir. Bu sebeple bu araştırmada Web 2.0 araçları ile desteklenmiş FeTeMM (Fen, Teknoloji, Matematik ve Mühendislik) etkinliklerinin geliştirilmesi ve öğrencilerin işbirlikli öğrenme yöntemiyle dersin işlenmesine yönelik görüşleri incelenmiştir.

\section{Araştırmanın Amacı}

Bu araştırmanın genel amacı, Fen Bilimleri dersinde işlenen biyo-çeşitlilik konularına yönelik FeTeMM etkinliği geliştirilmesi ve öğrencilerin geliştirilen işbirlikçi öğrenme ortamına yönelik görüşlerinin incelenmesidir. Bununla birlikte öğrencilerin gelişim gereksinimlerini karşılamaya dönük bir FeTeMM etkinliğinin planlanması ve bu öğretim ortamını kullanan öğrencilerin algılarının ve deneyimlerinin incelenmesi de hedeflenmiştir. Bu doğrultuda aşağıdaki sorulara yanıt aranmıştır:

1. Öğrencilerin Web 2.0 araçlarıyla desteklenmiş FeTeMM etkinliklerinin öğretim amaçlı kullanılmasına ilişkin görüşleri nedir?

2. Web 2.0 araçlarıyla desteklenmiş FeTeMM etkinliklerinin öğrenciler tarafından yapılabilme süreci, algılarıve deneyimleri nasıldır?

3. Öğrencilerin FeTeMM öğretim ortamının İşbirlikli Öğrenme yöntemiyle harmanlanması ile ilgili görüşleri nelerdir?

4. Öğrencilerin işbirlikli öğrenme ortamı hakkındaki deneyimleri ve görüşleri nasıldır?

\section{Yöntem}

$\mathrm{Bu}$ çalışma ortaokul öğrencilerinin Web 2.0 araçları ile desteklenmiş FeTeMM (Fen, Teknoloji, Matematik ve Mühendislik) etkinliklerinin geliştirilmesi ve öğrencilerin işbirlikli öğrenme yöntemiyle dersin işlenmesine yönelik görüşlerinin incelenmesi amacıyla yapılmış betimsel yapıda nitel bir araştırmadır. Betimsel araştırmalar, verilen bir durumu olabildiğince tam ve dikkatli bir şekilde tanımlamaktadır (Büyüköztürk, Çakmak, Akgün, Karadeniz \& Demirel, 2014: 22) . Nitel veri analizi konusunda son yıllarda yapılan ve hızla gelişen nitel araştırmalarda ortak bir dilin geliştiğinden söz edebilmek mümkün değildir. Nitekim nitel veri analizini merkeze alan temel başvuru kaynakları incelendiğinde birbirinden oldukça farklı analiz yöntem ve teknikleri ile karşılaşmak mümkündür (Dey, 1993; Özdemir, 2010). Bu sebeple, var olan görüşlerin belirlenmesi amaçlandığından nitel araştırma tekniklerinden yarı yapılandırılmış görüşme yöntemine başvurulmuştur. 


\section{Çalışma Grubu}

Çalışma grubu, Konya Selçuklu Sancak Ortaokulu 2016-2017 yı11 7. sınıfa devam eden 6 Kız ve 6 Erkek öğrenciden oluşmaktadır. Çalışma grubu oluşturulurken öğrenciler arasından seçkisiz örneklem oluşturma yönteminden yararlanılmıştır. Öğrenci grupları 4 kız, 4 erkek ve 2 kız,2 erkek olarak oluşturulmuştur.

\section{Veri Toplama Araçları}

Çalışmada veriler, araştırmacılar tarafindan oluşturulan ve uzman görüşleri doğrultusunda gerekli düzeltmeleri yapılan yarı yapılandırılmış görüşme formu ile toplanmıştır. Katılımcıların uygulamayı kullandıklarında gösterdikleri tepkiler ve çalışmaları video ile tespit edilmiştir.

FeTeMM Etkinliği Uygulama Şablonu

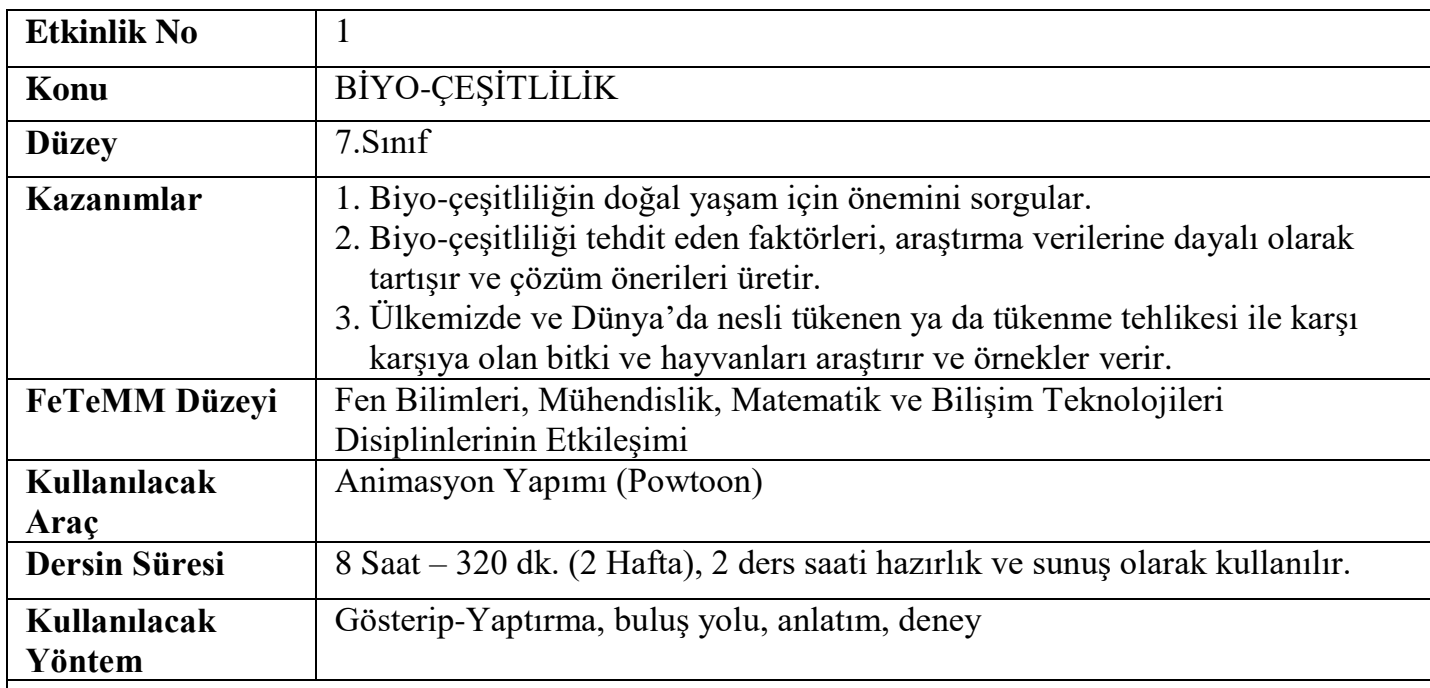

\section{UYGULAMA AŞAMALARI}

1. Öğrenciler 4'erli gruplara bölünür.

2. Gruplardan internet aracılığıyla konu ile ilgili doküman araştırmaları istenir. Bunları bir klasörde toplamaları istenir.

3. Önceden hazırlanmış olarak bir klasörde konu ile ilgili resimler ve metinler öğrenciler verilir.

4. Biyo-çeşitlilik konusunu anlatan çalışma kâğıdı verilir.

5. Öğrencilere biyo-çeşitlilik konusunda doğayı önleyici yapılabilecek işlemlerle ilgili deney yaptırılır. Deneyin aşamalarının notları ve resimlerini bir klasörde toplamaları istenir.

6. Animasyon için hikâye öğrencilere okunur. Bu doğrultuda animasyon yapacakları anlatıllır.

7. Animasyon yapma ile ilgili püf noktalar anlatılır. Çoklu ortam tasarım ilkelerinden bahsedilir.

8. Boş bir kâğıda animasyonun sahnelerinde öğrencilerden ne yapılabileceklerini tasarlamaları istenir. Gruplara öğretmen desteği sağlanır.

9. Powtoon Web 2.0 aracı öğrencilere tanıtılır. Örnek bir animasyon yapılması gösterilir.

10. Öğrencilere önceden hazırlanan Powtoon çalışma kâğıdı dağıtılır. Site adresi söylenir.

11. Powtoon'a üye olabilecekleri veya facebook-google üzerinden giriş yapabilecekleri bilgisi aktarilır.

12. Konuyla ilgili animasyon yapmaları istenir.

13. Animasyon yapmaları için yeterli süre verilir. Yaşanan problemlerde gerekli yardım araştırmacı ve ders öğretmeni tarafından sağlanır.

\section{Sahnelerde;}

Öğrenci biyo-çeşitlilik ve doğamızın katledilmesi hakkında animasyon hazırlar.

a. Öğrenci konuyu dikkate çekmek için bir giriş sahnesi yapar.

b. Dünyada nesli azalan canlı türlerini gösteren bir grafik yapıyı anime eder. 
c. Bu canlıların neden yok olma tehlikesinde olduğunu gösteren bir şablon oluşturur.

d. Ne tür çevre kirliliği oluştuğunu gösteren veya yok olma tehlikesi yaşayan canlıları gösteren sayfalar oluşturulur. Bununla ilgili yaptıkları araştırma ve deney aşamaları gösterilebilir.(En az üç sayfa oluşturulur.)

e. Herkesin doğanın ve biyo-çeşitliliğin yok olmasını önlemek için yapabileceği durumlara dikkat çekilir.

f. Bir slogan ile animasyon bitirilir.

\section{Animasyon Konu Şablonu;}

Yapılacak olan doğamız yok olmasın spotu hazırlanacaktır. Konu ile ilgili sizlerde slogan ve eklemeler yapabilirsiniz.

Örneğin; İntro sayfasında spotunuzun başlı̆̆ ve kendinizi tanıtabilirsiniz. Daha sonra insanların biyo-çeşitlilik konusunda dikkatlerini çekmek için Dünya'da canlıların ilginç özelliklerini söyleyebilirsiniz. Diğer bir sahnede Dünya'da biyo-çeşitliliği tehlikeye sokacak tutum ve durumlardan bahsedecek ekran yapılır. Nesli tükenen canlıların durumunu gösteren bir grafik veya infografik sahne oluşturulur. Önceden yapılan biyo-çeşitliliği koruyucu deney fotoğrafları ile yapılan hatalar nasıl düzeltileceği bahsedebilirsiniz. Konumuzu uygun uyarı notları ve slogan ile animasyon bitirebilirsiniz.

\section{Öğrencilerin FeTeMM etkinliğ̣i kapsamında öğreneceği disiplinler,}

- Matematik: Grafik okuma ve grafik oluşturma

- Bilişim Teknolojileri: Powtoon kullanımı, tasarım oluşturma, tablo yapma, Web 2.0 araç kullanımı

- Mühendislik: Biyo-Çeşitliliği önleyici ürün ortaya koyma ve tasarlama

- Fen Bilimleri: Biyo-çeşitlilik konusunun anlaşılması ve yapılabilecek önlemlerin farkına varılmas1

Öğrencilere etkinlik boyunca araştırmacı tarafından gözlenecektir. Etkinliğinin bitiminden sonra ders işlenişi ve işbirlikli öğrenme hakkındaki düşünceleri ile ilgili görüşme yapılacaktır. Ardından araştırmacı tarafından hazırlanan yarı yapılandırılmış görüşme formu doldurttular.

\section{Katılımcıların Geliştirdiği FeTeMM Spotu Örneği}

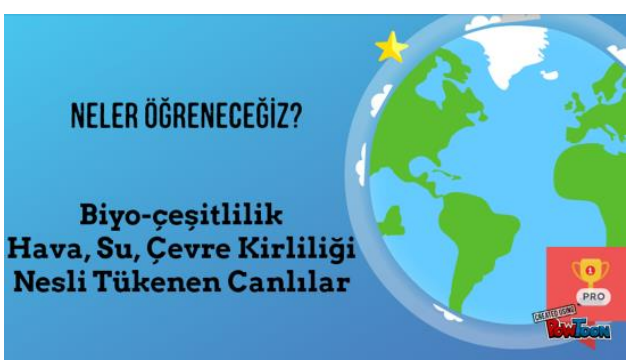

Şekil 3. Giriş Ekranı

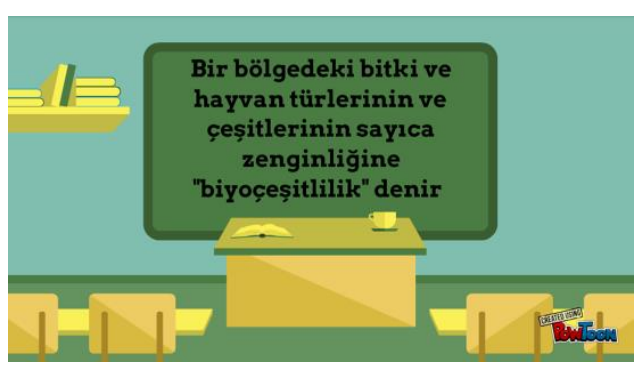

Şekil 4. (a) Konu Anlatımı 


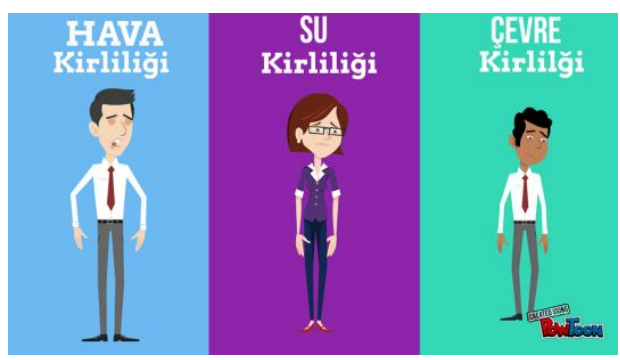

Şekil 4. (b) Konu Anlatımı

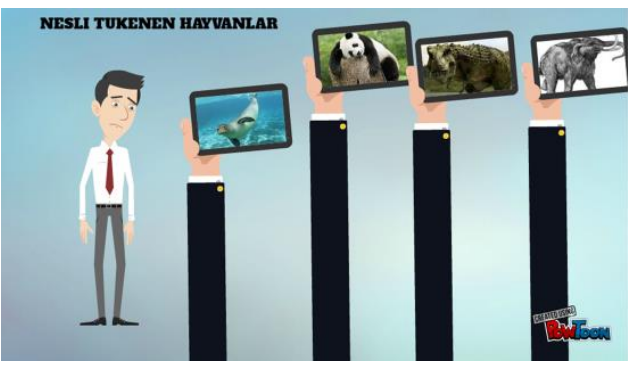

Şekil 4. (d) Konu Anlatımı

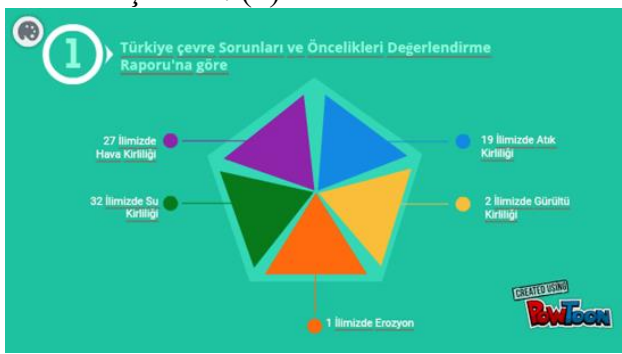

Şekil 5. Grafiksel Konu Anlatımı

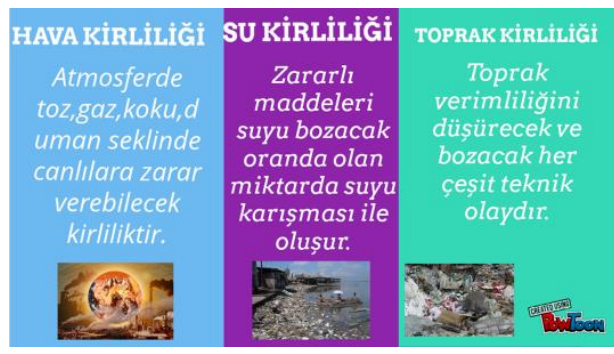

Şekil 4. (c) Konu Anlatımı

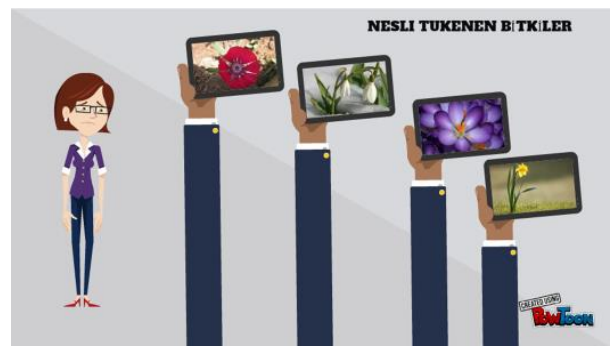

Şekil 4. (e) Konu Anlatımı

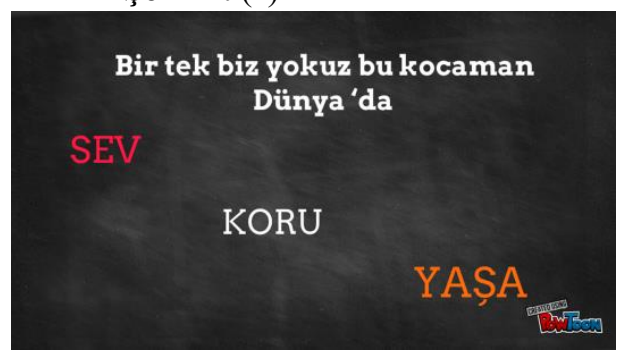

Şekil 6. Slogan ve Bitiş

\section{Bulgular}

Öğrenciler geliştirilmiş FeTeMM öğretim ortamında verilen görevleri yerine getirmiştir. Öğrenciler, 2 haftalık Fen Bilimleri dersibiyo-çeşitlilik konusu içeriğini (4+4 Ders Saati) verilen süre içerisinde tamamlamıştır. Öğrencilerin öğretim ortamı sırasında problem yaşamamaları için uygun boş bir sınıfta ve kütüphanede FeTeMM etkinlikleri yapılmıştır. Öğretim sürecinin nasıl gerçekleştiğini incelemek için video kaydı yapılmıştır. Öğrencilerin yaşadıkları problemler ve kullanım sırasındaki mimik ve hareketleri video kaydına alınmıştır. Öğrenciler FeTeMM etkinliklerinden sonra yarı yapılandırılmış İşbirlikli Öğrenme ve Derse İlişkin Görüş Formunu doldurmuşlardır. Öğrencilere video kaydı sırasında süreçle ilgili görüşleri ve geliştirilen öğretim ortamı hakkında genel düşünceleri sorularak kayıt altına alınmıştır. Yarı yapılandırılmış görüşme formu ve video kayıtları sonucunda:

Bulgular verilirken kullanıcılar aşağıdaki şekilde kodlanmıştır.

G1-ÖK:Grup 1 Kız Öğrenci, G1-ÖE:Grup 1 ErkekÖğrenci, G1-LÖ: Grup 1 Lider Öğrenci, G2ÖE:Grup 2 Erkek Öğrenciler, G2-LÖ: Grup 2 Lider Öğrenci, G3-ÖK:Grup 3 Kız Öğrenciler, G3-LÖ: Grup 3 Lider Öğrenci.

\section{1. Öğrencilerin Web 2.0 araçlarıyla desteklenmiş FeTeMM etkinliklerinin öğretim amaçlı kullanılmasına ilişkin görüşleri ve bulgular:}

Araştırmacılar tarafindan geliştirilen öğretim ortamı hakkında öğrencilerin tamamı olumlu görüş bildirmiştir. Grup liderlerinin görüşleri; G1-LÖ(G1-ÖK1) kodlu öğrenci geliştirilen öğretim ortamı ile 
öğrenilecek konunun animasyon hazırlık aşamasında farkında olmadan öğrendiklerini dile getirmiştir. G2L̈̈(G2-ÖE1) ise, görsel temaların fazla olmasından dolayı bilgilerin kalıcı olduğunu ve süreci sıkılmadan tamamladıklarını belirtmiştir. G3-LÖ (G3-ÖK1) kodlu grup lideri ise geliştirilen öğretim ortamının eğlenceli olduğunu ve normal ders süresinden daha kısa sürede birçok bilgi öğrendiklerini belirtmiştir. Ayrıca “Bu yöntemin ĕgitim-öğretimde mutlaka olmalıdır” olarak ifade etmiştir. Diğer grup üyelerinden

G1-ÖK2ve G1-ÖE2, konuyu sıkılmadan öğrendiklerini ve zaman kullanımı açısından kısa sürede uygulamaları bitirdiklerini belirtmiştir. Fakat gruba verilen bir bilgisayarın ikiye çıkarılması geliştirilen animasyonun daha iyi olmasını sağlayacağını belirtmiştir. G1-ÖE1 ise geliştirilen etkinliklerin uygulanmasında ilk başlarda biraz zorlandığını fakat öğretim ortamının eğlenceli olduğunu belirtmiştir. İncelenen video kayıtlarında G1-ÖE1'ün derslere zamanında gelmediği ve belli bölümleri kaçırdığı görülmektedir. Bu durum öğrencinin öğretim ortamındaki motivasyonunun olumsuz yönde etkilendiği görülmektedir.

G2-ÖE2ve G2-ÖE3 kodlu öğrenciler Fen Bilimleri dersinin hep böyle işlenmesi gerektiğini belirtmiştir. Bu sayede öğretimin kalıcı olacağını ve kolay öğrenilebileceğini vurgulamıştır. G2-ÖE4 kodlu öğrenci, "Öğretim sürecinde ĕglendim fakat zaman zaman öğretmenin konuyu anlatmasına ihtiyaç duydum. ”olarak görüş belirtmiştir. Öğretmenin özet olarak konuyu anlatmasının öğrenmelerine faydalı olacağını belirtmiştir.

G3-ÖK2, G3-ÖK3 ve G3-ÖK4 kodlu öğrenciler geliştirilen öğretim ortamı ile konuyu öğrenmenin kolay olduğunu ve araştırmalar sırasında farklı birçok bilgiyi de öğrendiklerini dile getirmiştir. Ayrıca bu yöntemin keyifli olduğunu ve akılda kalıcı olduğunu vurgulamıştır.

\section{2. Öğrencilerin Web 2.0 araçlarıyla desteklenmiş FeTeMM etkinlikleri yapabilme süreçleri,} algıları ve deneyimleri ile ilgili bulgular:

Öğrenciler tarafından FeTeMM etkinliklerini yapabilme becerileri ve deneyimleri olumlu olarak görülmektedir. Öğrencilerin araştırma sırsında internetin ara sıra kopması veya yavaşlaması süreçte bazı olumsuzluklar oluşturmuştur. Animasyonu ilk defa yapan öğrencilerimizin bilgisayar becerilerinde unuttukları bazı işlevleri hatırladıkları görülmüştür. Web 2.0 aracını ilk defa kullandıklarından dolayı bazı zorluklar çektikleri tespit edilmiştir. G1-LÖ (G1-ÖK1) kodlu öğrenci, geçmiş dönemlerde unuttuğu bazı bilgisayar becerilerini unuttuğu ve bu öğretim ortamı ile tekrar hatırladığını belirtmiştir. Animasyon yaparken ilk defa Web 2.0 aracı kullandığını ve bu sebeple ilk zaman zorlandıklarını fakat sonra kolaylıkla kullandıkları dile getirmiştir. Grup üyelerinden G1-EÖ1, gerek geç kalması gerekse lider olma isteği süreçten olumsuz etkilendiğini göstermektedir. G2-LÖ, animasyon yapmanın bu şekilde kolay yapılabildiğini ve konuyu öğrenirken eğlendiklerini dile getirmiştir. Video kayıt incelemelerinde, grubun teknoloji kullanım becerisi yüksek arkadaşlarının bilgisayar başına geçirmeleri görülmektedir. Bu sayede lider öğrenci koordinasyonunda öğrendikleri bilgiler ile yapılan animasyonun hızlıca bittiği görülmektedir. Grup 2 üyelerinin internet problemi yaşamaları süreci olumsuz yönde etkilemiştir. G3-LÖ grup lideri ise süreci beğendiklerini fakat bilgisayar kullanımı sırasında zorlandıklarını dile getirmiştir. Ayrıca "Yaşanan zorluklar ile özgüvenim gelişti ve zorluklar karşısında mücadele edebildim.”ifade etmiştir. Sürecin eğlenceli olduğu ve eğitim ortamında kullanılması gerektiğini dile getirmiştir.

G1-ÖK2, zaman ayarlanması ve Web 2.0 aracı kullanmanın zor olduğunu fakat k1sa sürede öğrendiklerini belirtmiştir. Bazı zorlukları öğretmen yardımıyla aştıklarını ve süreçte eğlendiklerini dile getirmiştir. Video kayıtların grubun araştırma ve animasyon şablonu oluşturma bölümlerinde görev aldığ görülmektedir. Grupta iş dağılımı yaptıkları görülmektedir. Bu durum onların animasyon yaparken eğlendiklerini ve sürece pozitif etki bıraktığı tespit edilmiştir. G1-ÖE1 ise etkinlik uygulama günlerine geç geldiğinden dolayı süreç hakkında olumsuz yönde görüş bildirmiştir. Süreci kendi başına daha rahat yapabileceğini belirtmiştir. Sürecin eğlenceli olduğunu ama biraz zaman aldığını dile getirmiştir. G1-ÖE2 ise bilmediği konularda öğretmen ve arkadaşlarının tamamladığını belirtmiştir. Bu durumun derse olan ilgisini arttırdığı yönde görüş bildirmiştir. Öğretim ortamının başarılı olduğu ve bu şekilde derslerin işlenmesi gerektiğini dile getirmiştir.

G2-ÖE1, G2-ÖE2, G2-ÖE3 ve G2-ÖE4, geliştirilen öğretim ortamında eğlendikleri tespit edilmiştir. Fakat kısa süreli internet bağlantı sorunları nedeniyle Web 2.0 araç kullanımı sırasında bir müddet sıkıldıkları tespit edilmiştir. Yaşadıkları olumsuzluklara rağmen sürecin olumlu geçtiğini dile 
getirmişlerdir. Öğrencilerin bu sürecin etkisiyle derse olan ilgilerinin ve motivasyonlarının artacağı yönünde görüş belirtmişlerdir. Eğitim sürecinin internet bağlantı hızı dışında gayet iyi olduğu dile getirmişlerdir. Kolaylıkla etkinliklerin yapılabileceği yönde görüş belirtmişlerdir.

G3-ÖK1, geliştirilen öğretim ortamında eğlendiklerini fakat grup lideri olmakta biraz zorlandığı̆ı dile getirmiştir. Grup üyelerinden bazılarının etkinlik sırasında zaman zaman gruptan ayrı takılmaları grup ahengini bozduğu yönünde görüş belirtmiş̧ir. Ayrıca "Web 2.0 aracını kullandıkça planlanan animasyon şablonun dışına çıktık ve farklı yapılar ögrendik" ifade etmiştir. Bu durumun kendilerini olumlu yönde motivasyon yaptığını ve dersin nasıl geçtiği anlamadıkları yönünde görüş belirtmiştir. G3-ÖK2, G3-ÖK3 ve G3-ÖK4 sürecin kendilerine faydalı olduğunu ve sıkılmadan dersin kolay geçtiğini dile getirmiştir. Grup liderinin planlanan animasyon içeriğinin dışına çıktığını ve bu sayede daha başarılı bir ürün çıktığını belirmişlerdir. G3-ÖK3 ayrıca araştırma sırasında ve Web 2.0 araç kullanımı sırasında zorlandığını görülmüş ve grup üyeleri ile öğretmen desteğiyle süreçten olumlu ayrıldığı tespit edilmiştir.

3. Öğrencilerin FeTeMM öğretim ortamının işbirlikli öğrenme yöntemiyle harmanlanması ile ilgili görüşleri ve bulguları:

Öğrencilerin FeTeMM öğretim ortamında grup çalışması yapmaları sonucunda süreçle ilgili 10 öğrenci olumlu 2 öğrenci olumsuz olarak görüş belirtmiştir. Olumsuz görüş belirten öğrencilerin derslere geç katıldığı ve liderlik vasıfları belirgin olan öğrenciler olduğu tespit edilmiştir. Uygulanan yönteme tüm grup liderleri olumlu görüş belirtmiştir. G1-LÖ uygulanan yöntem sayesinde eski bilgisayar becerilerinin ve bir an da birçok dersin bilgilerini kullanması gerektiğini dile getirmiştir. Uygulama süreci boyunca arkadaşlarıyla eğlendiklerini ve zamanın nasıl geçtiğini anlayamadıklarını dile getirmiştir. Karma grup süreci ilk tamamlayan grup olduğu görülmektedir. Grup üyelerinin birbirleri arasında görev dağılımı yaptığ ve liderin sürecin tamamlanmasında grup arkadaşlarını aktif olarak kullandığı görülmektedir. G1-ÖE2 ve G1-ÖK2 ise grup çalışmasında uygulanan etkinliklerde bilgisayar ve fen becerilerinin geliştiği yönünde görüş belirtmiştir. G1-ÖE2 ise "Benim bilmediğim konularda arkadaşlarım bana yardımcı oldu onlar bilmediği zamanlarda ise ben yardımcı olmaya çalışstım” "şeklinde ifade etmiştir. G1-ÖE1 ise geliştirilmiş öğretim ortamı hakkında olumsuz görüş belirtmiştir. "Bu çalışmayı grup olarak değil tek olarak daha iyi yapabilirdim." olarak dile getirmiştir.

G2-LÖise "Grup arkadaşlarımızla beraber çalışırken birbirimizi eğlendirmemiz hoşuma gitti” şeklinde görüş belirtmiştir. Ayrıca konuyu bu şekliyle iyi anladıklarını ve derse olan katılımlarının en üst sevide olduğunu dile getirmiştir. Sadece erkeklerden oluşan bu grubun mimiklerinden oldukça eğlendikleri tespit edilmiştir. Grup liderinin görev dağılımını iyi planlamaması sebebiyle uygulama sırasında çeşitli sıkıntılar oluşmuştur.G2-ÖE2ise, FeTeMM etkinlikleriyle yaptıkları grup çalışması sayesinde yanlış bildiği birçok bilginin doğrusunu öğrendiğini ve G2-ÖE3 ile birlikte unuttuğum bilgisayar becerilerini hatırladığını belirtmiştir. G2-ÖE4 ise geliştirilen öğretim ortamında eğlendiğini ama bazı konuların netleşmesi için " Süreç olumlu bir katkı sağlamıştır fakat konuyu tam öğrenmem için öğretmenin bilgilerine ihtiyacım var" şeklinde görüş belirtmiş̧ir.

G3-LÖ ise işbirlikli öğrenmenin zaten eğlenceli bir süreç olduğunu bu şekliyle de iyi bir öğretim ortamı olduğunu belirtmiştir. Kız grubunda ise grup iki ayrıldığı görülmüştür. G3-ÖK1 ile G3-ÖK4 grubun ağır yükünü çekerken, G3-ÖK2 ve G3-ÖK3 grupta pasif olarak tespit edilmiştir. Fakat süreç içinde zamanla kaynaşmış ve eğlendikleri görülmüştür. G3-ÖK2 geliştirilen öğretim sisteminde bilgilerin kolay anlaşıldığını ve etkinlikler sayesinde aktif ders katılımı olduğunu belirtmiştir. G3-ÖK4 ise "Öğrenciler bu sistemi çok sevecekler" şeklide görüş belirtmiştir. G3-ÖK2 ise grup çalışmasını olumsuz olarak ifade etmiştir. Fakat FeTeMM etkinliğinden hoşlandığını dile getirmiştir.

\section{4. Öğrencilerin işbirlikli öğrenme ortamı hakkındaki deneyimleri ve görüşleri ve bulguları:}

G1-LÖ, "işbirlikli öğrenmede hoşuna giden ne oldu?" sorusuna grup üyelerinin 2 kız 2 erkek olmas1 animasyon yaparken farklı açılardan bakmalarını sağladığı ve süreçte eğlendiklerini dile getirmiştir. İşbirlikli öğrenmede fikir anlaşmazlığı olduğunu fakat etkinlikte ortak karar alabildiklerini dile getirmiştir. Ayrıca "Grup çalışması sayesinde arkadaşlarımın değişik özelliklerini ögrrendim.” şeklinde ifade etmiştir. Grup arkadaşlarıyla iletişim kurarken sıkıntı çekmediğini belirtmiştir. G1-ÖK2 ise "Grup arkadaşlarıyla 
animasyon yapmak çok hoşuma gitti. "şeklinde görüş belirtmiştir. Grup arkadaşlarıyla iletişiminin iyi olduğu ve arkadaşlarıyla yardımlaştığı tespit edilmiştir. G1-ÖE1 ise herkes bildiklerini birleştirdi ve grup çalışmasındaki sorunları çözebildikleri şeklinde görüş belirtmiştir. Bir diğer ifadesinde ise grup liderinin dikkatli seçilmesi yönünde görüş belirtmiştir. Derslere geç gelmesi sebebiyle grup içinde belli dönemlerde dışlandığı görülmektedir. Fakat zaman içinde kendini grup üyelerine kabul ettirmiş ve etkinliklerde aktif roller aldığ tespit edilmiştir. Çalışmanın kişiyi oyaladığı ve zamanını aldığı konusunda görüş belirtmiştir. İşbirlikli öğrenme ortamının kendine uygun olmadığı yönde olumsuz fikir beyan etmiştir. G1-ÖE2 ise "Grup liderinin her işi kendisinin üstlenmeyip bizlere dağıtması hoşuma gitti." şeklinde ifade etmiştir. Ayrıca grup çalışmasından sonra kendindeki becerileri fark ettiğini ve bundan sonra ödevleri ile sınıf içi etkinlere daha iyi yapacağı yönünde görüş belirtmiştir. "Grup üyelerinden geç gelen arkadaşım bilmeden her şeye karıştı̆̆l, liderin aksine fikirler beyan etmesi aramızdaki iletişimi olumsuz etkiledi. ” Şeklinde grup üyeleri arasındaki iletişime vurgu yapmıştır.

G2-LÖ,G2-ÖE1veG2-ÖE2, grup arkadaşlarıyla çalışırken çok eğlendiklerini ifade etmiştir. Ayrıca G2-LÖ, Grup arkadaşlarının iyi biri olmadığını düşündüğünü fakat süreç ilerledikçe yanlış düşündüğü ve iyi arkadaş olduklarını dile getirmiştir. Benzer bir şekilde G2-ÖE2ve G2-ÖE3, grup çalışması yaparken arkadaşlarının bilgilerinden faydalandığını ve samimi bir arkadaşlık oluştuğunu belirtmiştir. G2-ÖE1, Grup çalışmalarının verimli olması, "Grup arkadaşları arasında iletişimin iyi olması gerekmekte ve kullanılacak teknolojik araçların hızlı olması gerekmektedir.” şeklinde görüş belirtmiştir. G2-ÖE3 ise "Arkadaşlar arasında fikirlerin mutlaka paylaşılması gerekmektedir." şeklindeki yorumuyla grup çalışmasında dikkat edilmesi gereken noktayı belirtmiştir. G2-ÖE4, grup çalışmasında yaşanan sıkıntılarda öğretmenden destek aldıklarını ve bilmedikleri konularda yardım istediklerini dile getirmiştir. Ayrıca "Grup arkadaşım G2-ÖE2'nin bu kadar iyi bilgisayar kullandığını düşünmemiştim." şeklinde görüş belirtmiştir.

G3-LÖ, grup çalışmasında arkadaşlarından bazılarını yeteri kadar destek olmadığını ve sorumluluk almadığını belirtmiştir. Video kayıtlarında da G3-LÖ'nün ifade ettiği gibi 2 grup üyesinin bazen grup dışında hareket ettiği görülmektedir. Bu durum grup dinamiğini olumsuz etkilemiştir. Grup çalışmasında dikkat edilmesi gereken hususlarda ise, "Mümkün mertebe grup arkadaşlarımın samimi ve her görüşe açık olması ile zorluklarda yardım istemesi gerektiğini düşünüyorum.” şeklinde ifade edilmiştir. G3-ÖK2 ise etkinlik yapımı sırasında grup arkadaşlarının görüşlerinin mutlaka alınması gerektiğini belirtmiştir. Ayrıca grup çalışması ile arkadaşlarım arasında iletişiminin olumlu yönde geliştiğini dile getirmiştir. G3ÖK3veG3-ÖK4, grup çalışması yapılırken mutlaka görev dağılımın yapılması gerektiğini ifade etmiştir. Ayrıca G3-ÖK4, grup arkadaşlarının düşündüğünden daha iyi olduklarını belirtmiştir.

Yapılan video kaydı incelemelerinde ise, karma grubun diğer üyelere göre daha iyi anlaştıkları tespit edilmiştir. Erkek öğrenci grubunun bilgisayarda internet problemi yaşaması olumsuz düşünceler geliştirmelerine neden olmuştur. Grup 1 de ise liderlik yapmak isteyen iki öğrenci olması uygulama sırasında aksamalara neden olmuştur. Öğrencilerin Web 2.0 aracı kullanırken eğlendikleri görülmüştür.

\section{Tartışma ve Sonuç}

Alanyazında FeTeMM ile ilgili yapılan birçok çalışma vardır. Yıldırım ve Altun'ın(2015), FeTeMM eğitim ve mühendislik uygulamalarının fen bilgisi laboratuar dersindeki etkilerini araştırdıkları çalışmada öğrencilerin öğrenme düzeylerinde anlamlı bir artışın olduğu tespit edilmiştir (Yıldırım \& Altun, 2015). Bu durum öğrencilerin geliştirilen öğretim ortamının olumlu olmasıyla örtüşmektedir. Web 2.0 araçlarının öğretim amaçlı kullanılması öğretim sürecini eğlenceli hale getirdiği görülmektedir. Öğrencilerin FeTeMM etkinlikleri sayesinde farkında olmadan birçok beceriyi kullandıkları görülmektedir. Bu yönde çalışma yapan Germann, Aram ve Burke (1996) 7. sınıf öğrencileri üzerinde yaptıkları bir araştırmada fen laboratuarında yapılan deneylerin, öğrencilerin bilişsel süreç ve düşünce becerilerini geliştireceğini dile getirmiştir (Germann, Aram \& Burke, 1996). Sullivan'nın (2008) yapmış olduğu bir diğer araştırmada, ortaokul öğrencilerin FeTeMM etkinliklerinin öğrencilerin bilişsel süreç becerilerinin geliştiğini belirtmiştir (Sullivan, 2008). Bir diğer çalışmada Stohlmann, Moore ve Roehrig(2012), FeTeMM eğitim yönteminin mevcut sisteme entegre edilmesinde dikkat edilmesi gereken hususlar konusunda çalışmıştır. Araştırmasında öğrencilerin öğrendiklerini anlamlı hale getirmelerinde FeTEMM eğitiminin önemli olduğunu ve ortaokul düzeyinde geliştirilmesine dikkat çekmiştir (Stohlmann, Moore \& Roehrig, 2012). Bizim çalışmamızda öğrencilerin Web 2.0 araçlarıyla desteklenmiş FeTeMM etkinliklerinin öğretim amaçlı 
kullanılmasına ilişkin görüşlerinin olumlu yönde olduğu tespit edilmiştir. Ayrıca öğrencilerin yorumları, geliştirilen ortamının mevcut sisteme entegre edilmesi yönünde olmuştur.

Araştırmada ulaşılan diğer bir sonuca göre Web 2.0 araçlarıyla desteklenmiş FeTeMM etkinliklerinin öğrenciler tarafından yapılabilme süreci, algıları ve deneyimleri ise genel olarak olumlu olduğu tespit edilmiştir. Öğrenciler Web 2.0 araç etkinliğini yaparken bazı öğrenciler zorlandığını fakat kısa sürede aracın kullanımını çözdüğü görülmektedir.

Karahan, Cambazoğlu-Bilici ve Ünal (2015), 8. sınıf öğrencilerin yaptı̆̆ FeTeMM etkinliklerinde eğlendikleri ve keyif aldıklarını dile getirilmiştir (Karahan, Cambazoğlu-Bilici ve Ünal2015). Yapılan araştırmada da benzer olarak, Web 2.0 araç kullanımı FeTeMM eğitim ortamını eğlenceli hale getirdiği tespit edilmiştir.

Çavaş, Bulut, Holbrook ve Rannikmae (2013) deyapmış olduğu tasarım tabanlı fen eğitimlerinin öğrencilerin ilgi ve isteklerini arttırdığı yönünde tespitte bulunmuştur (Çavaş, Bulut, Holbrook ve Rannikmae, 2013). Yapılan araştırmada bu duruma paralel olarak;öğrencilerin Web 2.0 araçlarıyla geliştirilmiş öğretim ortamını beğendiği ve konuyu öğrenme isteklerinin arttı̆̆ görülmüştür.FeTeMM etkinliklerinde internet ve bilgisayar kullanılması durumunda alt yapının iyi olması süreci olumlu etkileyecektir. Öğrencilerin internet hızından zaman zaman rahatsız oldukları görülmüştür.

Şahin, Ayar ve Adıgüzel (2014) yaptığı araştırmada FeTeMM etkinlikleri sırasında öğrencilerin grup çalışmaları yapması, işbirliği gibi 21.yy becerilerinin geliştiğini ifade etmiş̧tir (Şahin, Ayar \& Adıgüzel, 2014). Araştırmada bu durumu destekler nitelikte öğrencilerin Web 2.0 destekli FeTeMM öğretim ortamının İşbirlikli Öğrenme yöntemiyle harmanlanmasını olumlu bulmuşlardır. Öğrencilerin işbirlikli öğrenme ortamında birbirlerine destek olması süreci olumlu yönde etkilemiştir. Yapılan etkinliklerde grup üyelerinin iş bölümü yapmaları ve birbirlerine yardım etmelerinin çıkarılan ürünün kalitesini arttırdığı görülmüştür. Ayrıca grup üyelerinde lider özelliği güçlü öğrenciler olması etkinliklerin başarıyla yapılmasında etkili olmuştur. Grup üyelerinin farklı düşüncelerde olması FeTeMM etkinliklerinde farklı yorumlar geliştirmelerine yardımcı olmuştur. Öğrenciler bir sorunla karşılaştıklarında, bu sorunları çözdükleri tespit edilmiştir. Geliştirilen öğretim ortamı sayesinde öğrencilerin problem çözme becerilerinin geliş̧tiği düşünülmektedir.

Öğrencilerin işbirlikli öğrenme ortamı hakkındaki deneyim ve görüşlerinin genel olarak pozitif yönde olduğu görülmektedir. Karma grubun diğer gruplara göre olaylara ve etkinliklere daha farklı açıdan yaklaştıkları görülmüş̧ür. Erkek öğrenci grubu ise süreç boyunca diğer gruplara göre arkadaşlarıyla uyumlu ve iletişimlerinin güçlü olduğu tespit edilmiştir. Sadece kız öğrenci grubunda ise istenilen düzeyde grup lideri olmadığından süreç içinde bazen bölündükleri görülmüştür. Grup çalışması sırasında öğrencilerin dersin işleniş süresi boyunca sıkılmadan istenilenleri yaptıkları görülmüştür. Grup çalışmasıyla içe dönük ve başarısız olduğunu düşünen öğrencilerde özgüvenlerinin geliştiği tespit edilmiştir. Grup çalışmalarında öğrencilerin geliştirilen eğitim ortamında aktif olması sürecin başarısını olumlu yönde etkilemiştir. $\mathrm{Bu}$ sebeple Web 2.0 araçlarıyla desteklenmiş FeTeMM etkinliklerinin öğrencilerin aktif katılımını sağlayacak nitelikte hazırlanması gerektiğini düşünmekteyiz.

\section{Teşekkür ve Bilgilendirme}

Bu çalışma ICITS (International Computer \& Instructional Technologies Symposium) 2017'de sözlü bildiri olarak sunulmuştur. 


\section{References}

Ayar, M.C.,Yalvac, B., Ugurdag, F., \& Sahin, A. (2013). A Robotics Summer Camp for High School Students: Learning About Engineering Design at First Hand and Career Interest in Engineering. Proceedings ofthe American Societyfor Engineering Education (ASEE), Atlanta, GA, USA: June 2326, 2013.

Atkinson, R. D., \& Mayo, M. J. (2010). Refueling the US Innovation Economy: FreshapProachesto Science, Technology, EngineeringandMathematics (STEM) Education. The Information Technology \& Innovation Foundation, Forthcoming.

Aydeniz, M., Çakmakçı, G., Çavaş, B., Özdemir, S., Akgündüz, D., Çorlu, M.S., \& Öner, T. (2015). STEM Eğitimi Türkiye Raporu: "Günün Modası mı? Yoksa Gereksinim mi? [A report on STEM Education in Turkey: A provisional agenda or a necessity?] İstanbul Aydın Üniversitesi. STEM Merkezi ve Eğitim Fakültesi.

Baran, E., Canbazoğlu-Bilici, S., \& Mesutoğlu, C. (2015). Fen, Teknoloji, Mühendislik ve Matematik (FeTeMM) Spotu Geliştirme Etkinliği. [Science, Technology, Engineering, And Mathematics (STEM) Public Service Announcement (Psa) Development Activity]. Araştırma Temelli Etkinlik Dergisi, 5(2), 60-69.

Corlu, M. S.,Capraro, R. M., \& Capraro, M. M. (2014). Introducing STEM Education: Implications for Educating our Teachers for the Age of Innovation. Eğitim ve Bilim, 39(171).

Çavaş, B., Bulut, Ç., Holbrook, J., \& Rannikmae, M. (2013). Fen Eğitimine Mühendislik Odaklı Bir Yaklaşımı: ENGINEER Projesi ve Uygulamaları. [An Engineering Focused Approach to Science Education: ENGINEER Project and Applications]. Fen Bilimleri Ögretimi Dergisi, 1(1), 12-22.

Gencer, A. S. (2015). Fen Eğitiminde Bilim ve Mühendislik Uygulaması: Fırıldak Etkinliği. [Scientific And Engineering Practices in Science Education: Twirly Activity]. Araştırma Temelli Etkinlik Dergisi, 5(1), 1-19.

Germann, P. J., Roberta,A. \& Gerald B. (1996). Identifying Patterns and Relationships Among the Responses of Seventh-Grade Students to the Science Process Skill of Designing Experiments. Journal of Research in Science Teaching, Vol. 33 (1): 79-99.

Gündüz, S., \& Odabası, F. (2004). Bilgi Çağında Öğretmen Adaylarının Eğitiminde Öğretim Teknolojileri ve Materyal Geliştirme Dersinin Önemi. [The Importance Of Instructional Technologies and Material Development Course At Pre-Service Teacher Education in Information Age]. TOJET: TheTurkish Online Journal of Educational Technology, 3(1).

Karahan, E.,Canbazoglu-Bilici, S., \& Unal, A. (2015). Integration of Media Design Processes in Science, Technology, Engineering, and Mathematics (STEM) Education. Eurasian Journal of Educational Research, 60, 221-240 Doi: 10.14689/ejer.2015.60.15.

Kayaduman, H.,Sırakaya, M., \& Seferoğlu, S. S. (2011). Eğitimde FATİH Projesinin Öğretmenlerin Yeterlik Durumları Açısından İncelenmesi. [Investigation of "Increasing Opportunities and Improvement of Technology" Project in Terms of Teacher Competencies]. Akademik Bilişim, 11.

Moore, T.J.,Stohlmann, M.S., Wang, H.-H., Tank, K.M., \& Roehrig, G.H. (2013). Implementationand Integration of Engineering in K-12 STEM Education. In J. Strobel, S. Purzer, \& M. Cardella (Edt.), Engineering in Precollege Settings: Researchinto Practice. Rotterdam, theNetherlands: Sense Publishers

Sullivan, F. R. (2008). Robotics and Science Literacy: Thinking Skills, Science Process Skills and Systems Understanding. Journal of Research in Science Teaching, 45(3), 373-394.

Stohlmann, M.,Moore, T. J., \&Roehrig, G. H. (2012). Consider Ationsfor Teachingin Tegrated STEM Education. Journal of Pre-CollegeEngineeringEducationResearch (J-PEER), 2(1), 4.

Şahin, A., Ayar, M. C., \& Adıgüzel, T. (2014). Fen, Teknoloji, Mühendislik ve Matematik İçerikli Okul Sonrası Etkinlikler ve Öğrenciler Üzerindeki Etkileri. [STEM Related After-School Program Activities 
and Associated Outcomes on Student Learning]. Educational Sciences: Theory \& Practice, 14(1), 297322.

Yamak, H., Bulut, N., \& Dündar, S. (2014). 5. Sınıf Öğrencilerinin Bilimsel Süreç Becerileri ile Fene Karş1 Tutumlarına FeTeMM Etkinliklerinin Etkisi. [The Impact of STEM Activities on 5th Grade Students' Scientific Process Skills and Their Attitudes Towards Science]. Gazi Üniversitesi. Gazi Eğitim Fakültesi Dergisi, 34(2).

Yıldırım, B.,\&Altun, Y. (2015). STEM Eğitim ve Mühendislik Uygulamalarının Fen Bilgisi Laboratuar Dersindeki Etkilerinin Incelenmesi. [Investigating the Effect of STEM Education and Engineering Applications on Science Laboratory Lectures]. El-Cezeri Journal of Science and Engineering, 2(2), 2848. 